\title{
LEVEL II SCOUR ANALYSIS FOR BRIDGE 27 (READTH00380027) on TOWN HIGHWAY 38, crossing the NORTH BRANCH BLACK RIVER, READING, VERMONT
}

Open-File Report 98-379

Prepared in cooperation with

VERMONT AGENCY OF TRANSPORTATION

and

FEDERAL HIGHWAY ADMINISTRATION

U.S. Department of the Interior U.S. Geological Survey

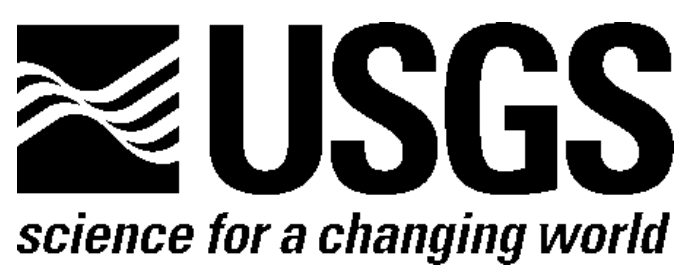




\section{LEVEL II SCOUR ANALYSIS FOR BRIDGE 27 (READTH00380027) on TOWN HIGHWAY 38, crossing the NORTH BRANCH BLACK RIVER, READING, VERMONT}

By MICHAEL A. IVANOFF AND MATTHEW A. WEBER

U.S. Geological Survey Open-File Report 98-379

Prepared in cooperation with

VERMONT AGENCY OF TRANSPORTATION

and

FEDERAL HIGHWAY ADMINISTRATION 


\title{
U.S. DEPARTMENT OF THE INTERIOR BRUCE BABBITT, Secretary
}

\author{
U.S. GEOLOGICAL SURVEY
}

Thomas J. Casadevall, Acting Director

For additional information write to:

District Chief

U.S. Geological Survey 361 Commerce Way

Pembroke, NH 03275-3718
Copies of this report may be purchased from:

U.S. Geological Survey

Branch of Information Services

Open-File Reports Unit

Box 25286

Denver, CO 80225-0286 


\section{CONTENTS}

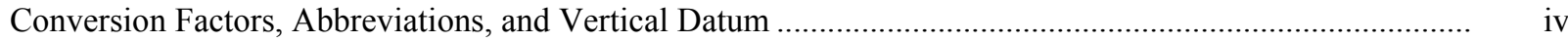

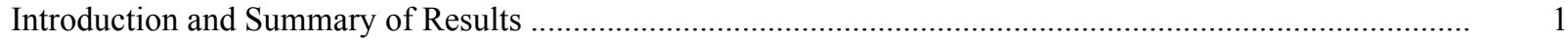

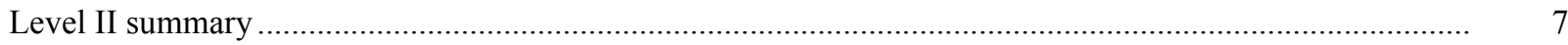

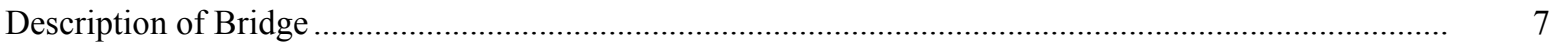

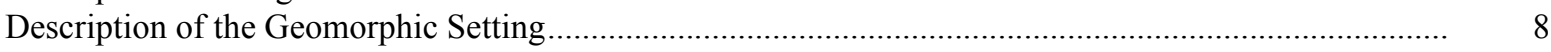

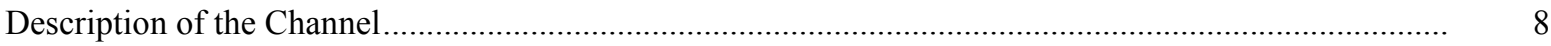

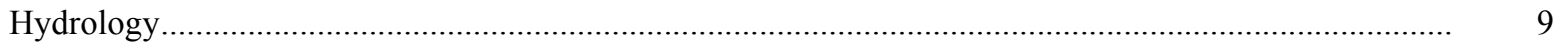

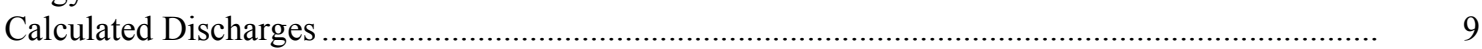

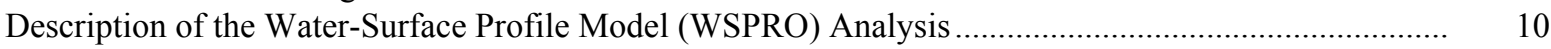

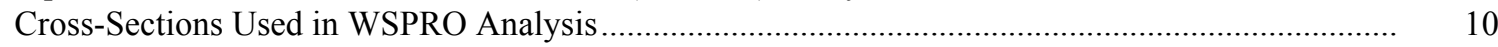

Data and Assumptions Used in WSPRO Model ........................................................................ 11

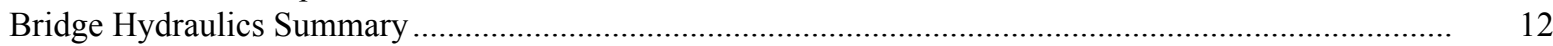

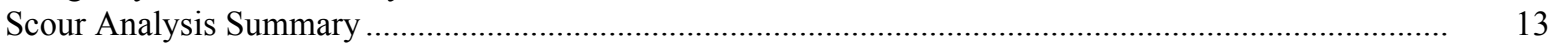

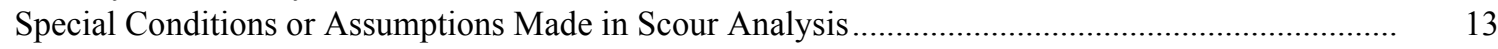

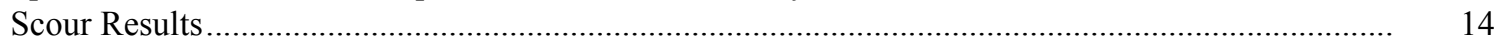

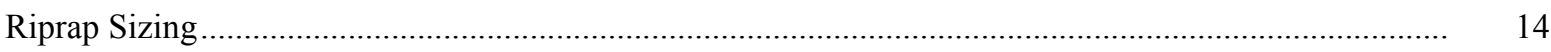

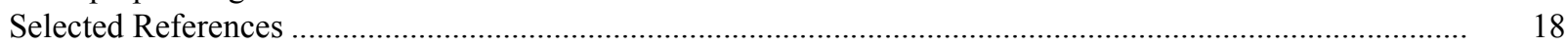

Appendices:

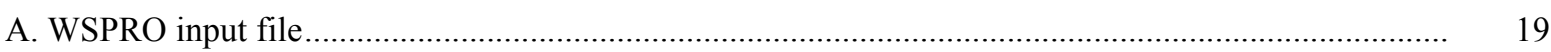

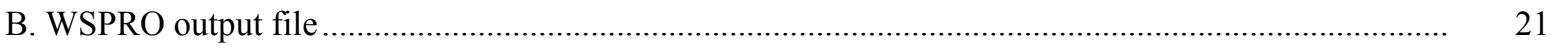

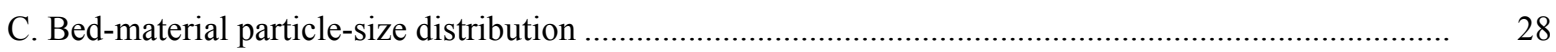

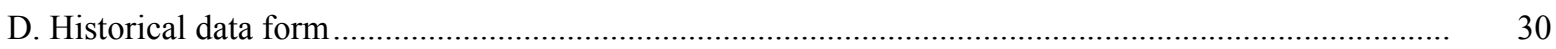

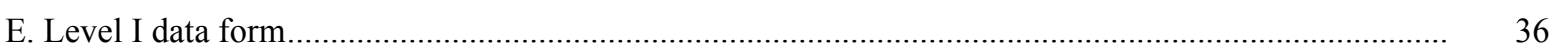

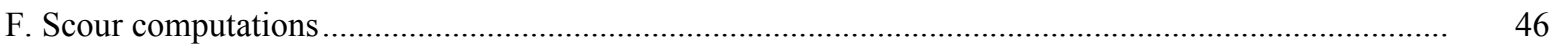

\section{FIGURES}

1. Map showing location of study area on USGS 1:24,000 scale map

2. Map showing location of study area on Vermont Agency of Transportation town highway map

3. Structure READTH00380027 viewed from upstream (March 29, 1995).

4. Downstream channel viewed from structure READTH00380027 (March 29, 1995) $\ldots . \ldots \ldots \ldots \ldots$

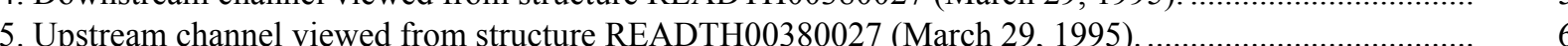

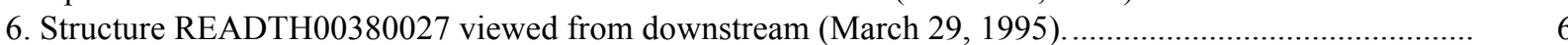

7. Water-surface profiles for the 100- and 500-year discharges at structure

READTH00380027 on Town Highway 38, crossing the North Branch Black River,

Reading, Vermont.

8. Scour elevations for the 100- and 500-year discharges at structure

READTH00380027 on Town Highway 38, crossing the North Branch Black River,

Reading, Vermont.

\section{TABLES}

1. Remaining footing/pile depth at abutments for the 100-year discharge at structure

READTH00380027 on Town Highway 38, crossing the North Branch Black River,

Reading, Vermont

2. Remaining footing/pile depth at abutments for the 500-year discharge at structure

READTH00380027 on Town Highway 38, crossing the North Branch Black River,

Reading, Vermont. 


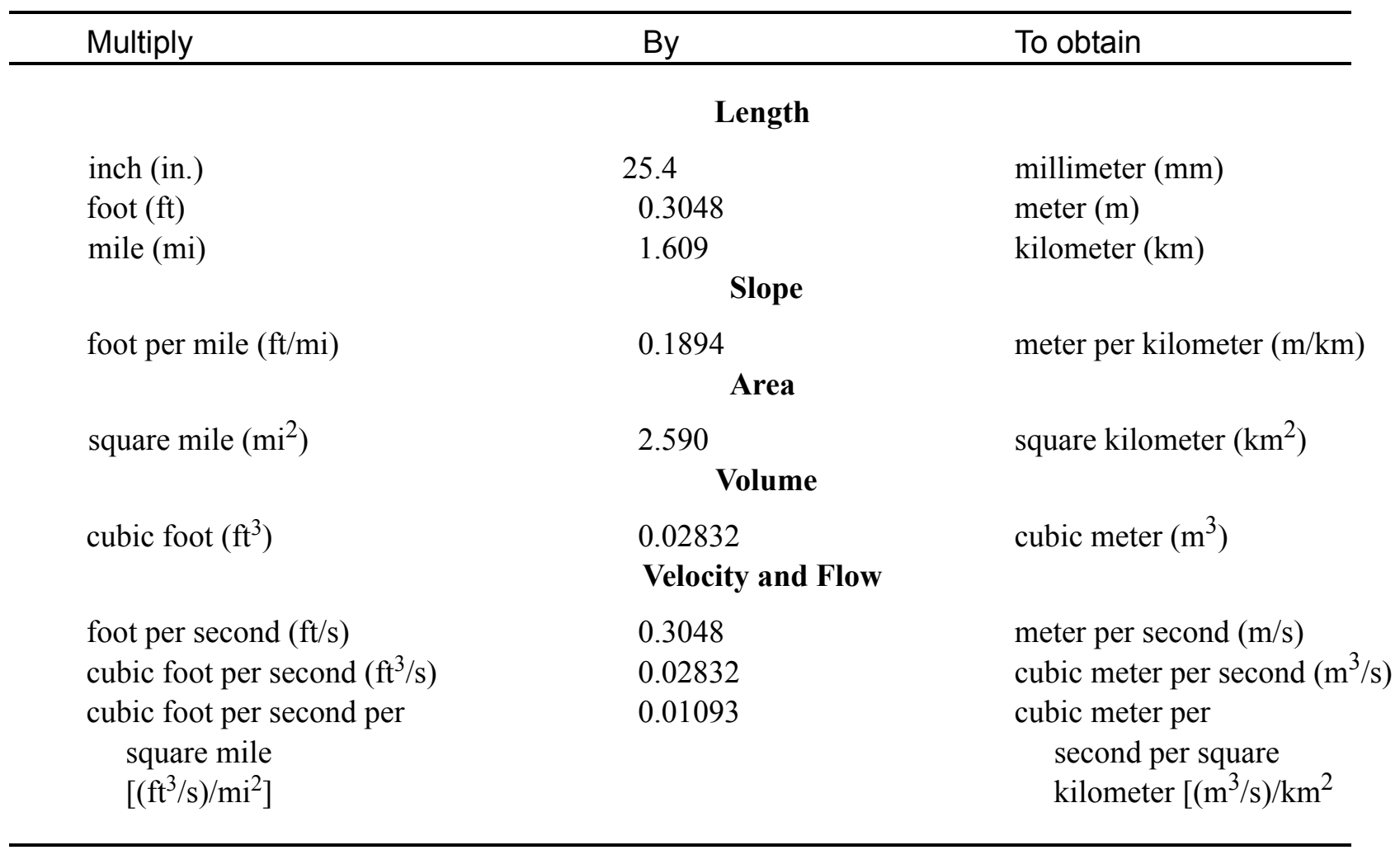

\section{OTHER ABBREVIATIONS}

$\begin{array}{lrlr}\mathrm{BF} & \text { bank full } & \text { LWW } & \text { left wingwall } \\ \mathrm{cfs} & \text { cubic feet per second } & \text { Max } & \text { maximum } \\ \mathrm{D}_{50} & \text { median diameter of bed material } & \text { MC } & \text { main channel } \\ \mathrm{DS} & \text { downstream } & \text { RAB } & \text { right abutment } \\ \mathrm{elev} & \text { elevation } & \text { RABUT } & \text { face of right abutment } \\ \mathrm{f} / \mathrm{p} & \text { flood plain } & \text { RB } & \text { right bank } \\ \mathrm{ft} & \text { square feet } & \text { ROB } & \text { right overbank } \\ \mathrm{ft} / \mathrm{ft} & \text { feet per foot } & \text { RWW } & \text { right wingwall } \\ \mathrm{FEMA} & \text { Federal Emergency Management Agency } & \text { TH } & \text { town highway } \\ \mathrm{FHWA} & \text { Federal Highway Administration } & \text { UB } & \text { under bridge } \\ \mathrm{JCT} & \text { junction } & \text { US } & \text { upstream } \\ \text { LAB } & \text { left abutment } & \text { USGS } & \text { United States Geological Survey } \\ \text { LABUT } & \text { face of left abutment } & \text { VTAOT } & \text { Vermont Agency of Transportation } \\ \text { LB } & \text { left bank } & \text { WSPRO } & \text { water-surface profile model } \\ \text { LOB } & \text { left overbank } & \text { yr } & \text { year }\end{array}$

In this report, the words "right" and "left" refer to directions that would be reported by an observer facing downstream. Sea level: In this report, "sea level" refers to the National Geodetic Vertical Datum of 1929-- a geodetic datum derived from a general adjustment of the first-order level nets of the United States and Canada, formerly called Sea Level Datum of 1929.

In the appendices, the above abbreviations may be combined. For example, USLB would represent upstream left bank. 


\title{
LEVEL II SCOUR ANALYSIS FOR BRIDGE 27 (READTH00380027) ON TOWN HIGHWAY 38, CROSSING THE NORTH BRANCH BLACK RIVER, READING, VERMONT
}

\author{
By Michael A. Ivanoff and Matthew A. Weber
}

\section{INTRODUCTION AND SUMMARY OF RESULTS}

This report provides the results of a detailed Level II analysis of scour potential at structure READTH00380027 on Town Highway 38 crossing the North Branch Black River, Reading, Vermont (figures 1-8). A Level II study is a basic engineering analysis of the site, including a quantitative analysis of stream stability and scour (FHWA, 1993). Results of a Level I scour investigation also are included in appendix E of this report. A Level I investigation provides a qualitative geomorphic characterization of the study site. Information on the bridge, gleaned from Vermont Agency of Transportation (VTAOT) files, was compiled prior to conducting Level I and Level II analyses and is found in appendix D.

The site is in the New England Upland section of the New England physiographic province in eastern Vermont. The $9.08-\mathrm{mi}^{2}$ drainage area is in a predominantly rural and forested basin. In the vicinity of the study site, the surface cover is forest.

In the study area, the North Branch Black River has an incised, sinuous channel with a slope of approximately $0.03 \mathrm{ft} / \mathrm{ft}$, an average channel top width of $66 \mathrm{ft}$ and an average bank height of $8 \mathrm{ft}$. The channel bed material ranges from gravel to cobble with a median grain size $\left(\mathrm{D}_{50}\right)$ of $66.9 \mathrm{~mm}(0.220 \mathrm{ft})$. The geomorphic assessment at the time of the Level I site visit on March 29, 1995 and the Level II site visit on October 12, 1995, indicated that the reach was laterally unstable with moderate to severe fluvial bank erosion.

The Town Highway 38 crossing of the North Branch Black River is a 36-ft-long, two-lane bridge consisting of one 35-foot steel-beam span (Vermont Agency of Transportation, written communication, March 9, 1995). The opening length of the structure parallel to the bridge face is $26.5 \mathrm{ft}$. The bridge is supported by vertical, concrete abutments with wingwalls. The channel is skewed approximately 50 degrees to the opening while the computed opening-skew-to-roadway is 5 degrees. 
A scour hole $2 \mathrm{ft}$ deeper than the mean thalweg depth was observed along the left abutment and the downstream left wingwall during the Level I assessment. The footing was undermined along the left abutment and the downstream left wingwall. The scour protection measures at the site include type- 2 stone fill (less than 36 inches diameter) at the upstream end of the upstream right wingwall and along the entire base length of the upstream left wingwall and type- 1 stone fill (less than 12 inches diameter) along the upstream left and right banks and the downstream left and right banks. Additional details describing conditions at the site are included in the Level II Summary and appendices D and E.

Scour depths and recommended rock rip-rap sizes were computed using the general guidelines described in Hydraulic Engineering Circular 18 (Richardson and Davis, 1995) for the 100- and 500-year discharges. In addition, the incipient roadway-overtopping discharge was determined and analyzed as another potential worst-case scour scenario. Total scour at a highway crossing is comprised of three components: 1) long-term streambed degradation; 2) contraction scour (due to accelerated flow caused by a reduction in flow area at a bridge) and; 3 ) local scour (caused by accelerated flow around piers and abutments). Total scour is the sum of the three components. Equations are available to compute depths for contraction and local scour and a summary of the results of these computations follows.

Contraction scour for all modelled flows ranged from 0.0 to $3.7 \mathrm{ft}$. The worst-case contraction scour occurred at the 500-year discharge. Abutment scour ranged from 6.9 to $17.4 \mathrm{ft}$. The worst-case abutment scour occurred at the 500-year discharge. Additional information on scour depths and depths to armoring are included in the section titled "Scour Results". Scoured-streambed elevations, based on the calculated scour depths, are presented in tables 1 and 2. A cross-section of the scour computed at the bridge is presented in figure 8. Scour depths were calculated assuming an infinite depth of erosive material and a homogeneous particle-size distribution.

It is generally accepted that the Froehlich equation (abutment scour) gives "excessively conservative estimates of scour depths" (Richardson and Davis, 1995, p. 46). Usually, computed scour depths are evaluated in combination with other information including (but not limited to) historical performance during flood events, the geomorphic stability assessment, existing scour protection measures, and the results of the hydraulic analyses. Therefore, scour depths adopted by VTAOT may differ from the computed values documented herein. 


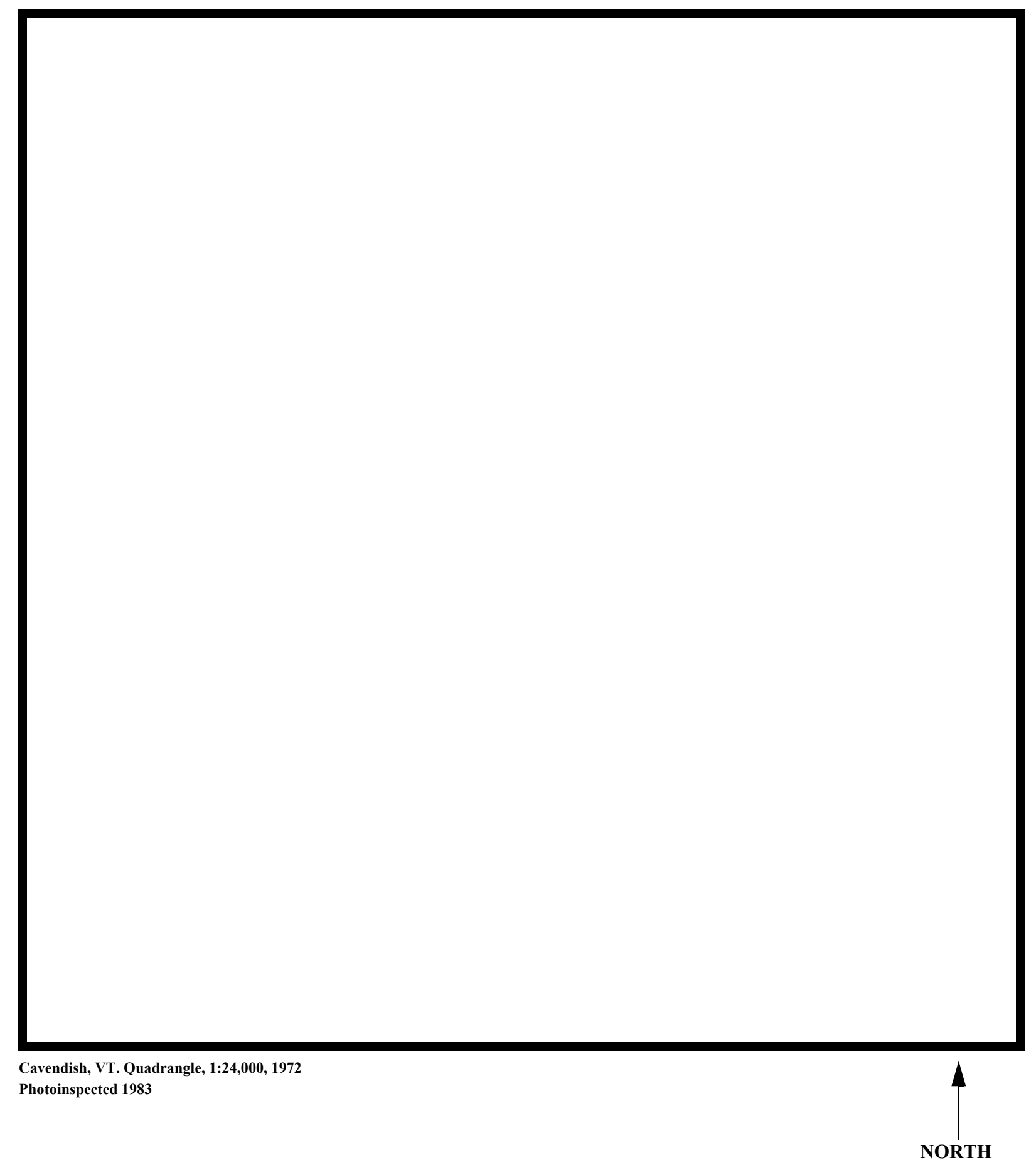

Figure 1. Location of study area on USGS 1:24,000 scale map. 
Figure 2. Location of study area on Vermont Agency of Transportation town highway map. 

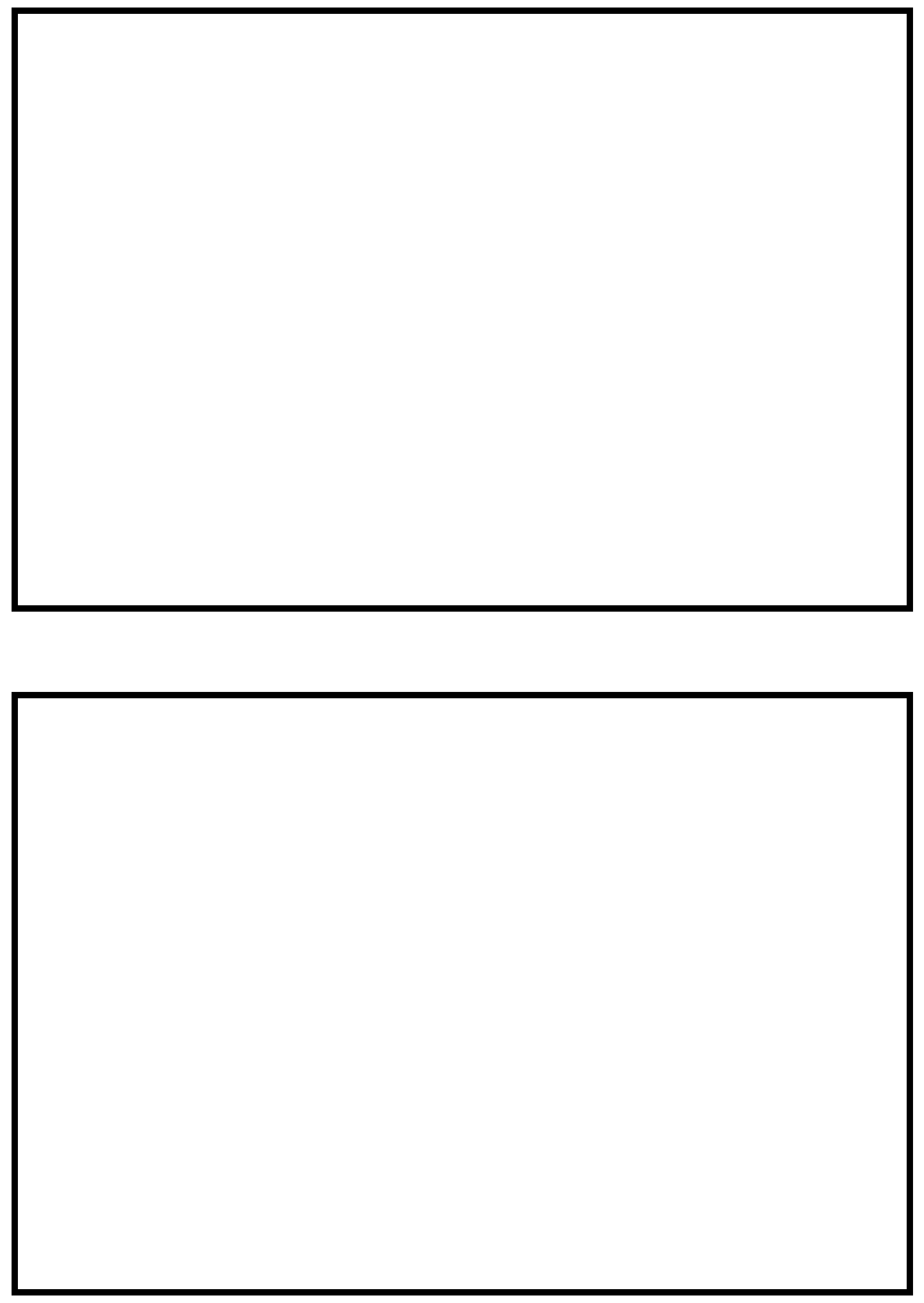

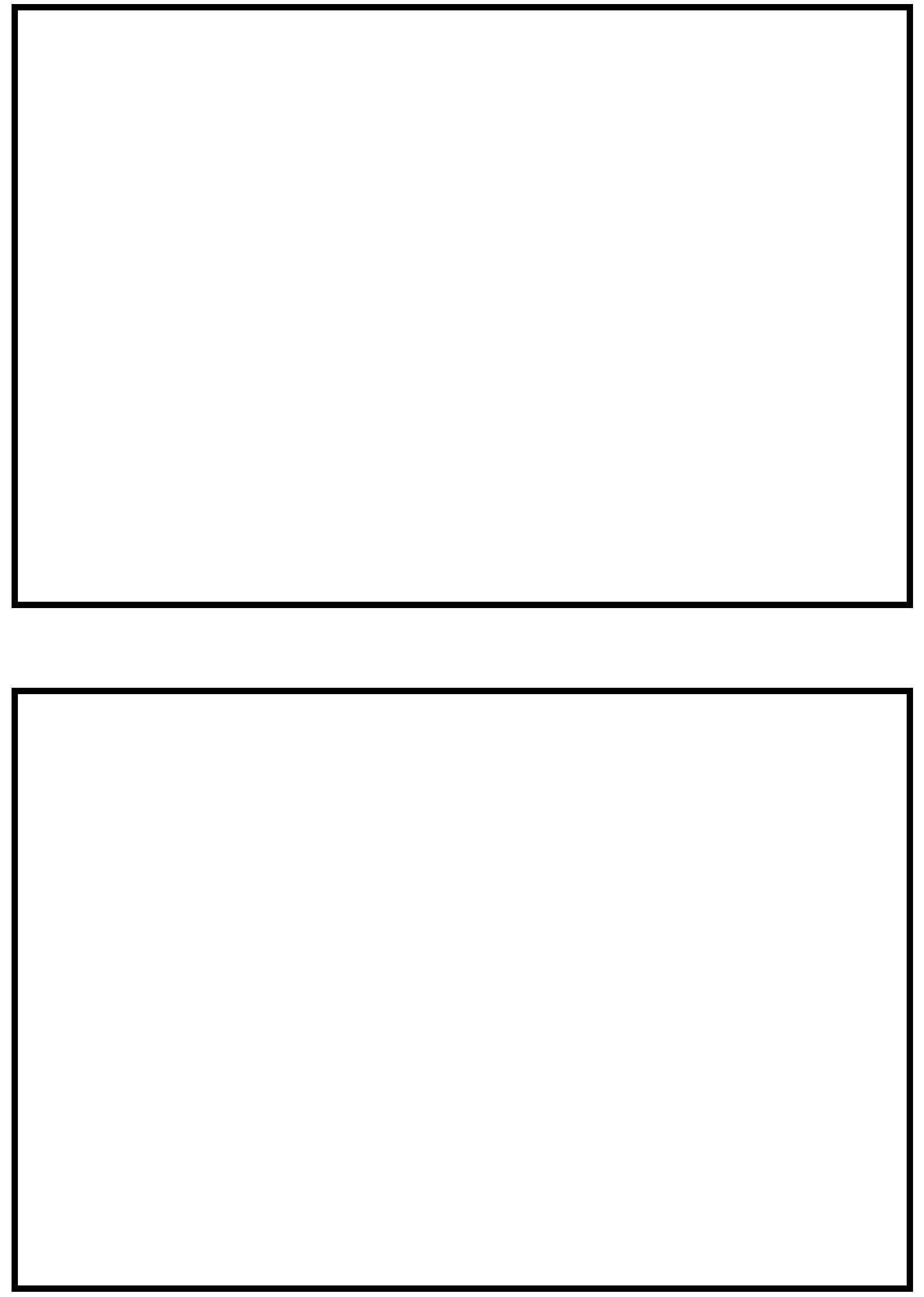


\section{LEVEL II SUMMARY}

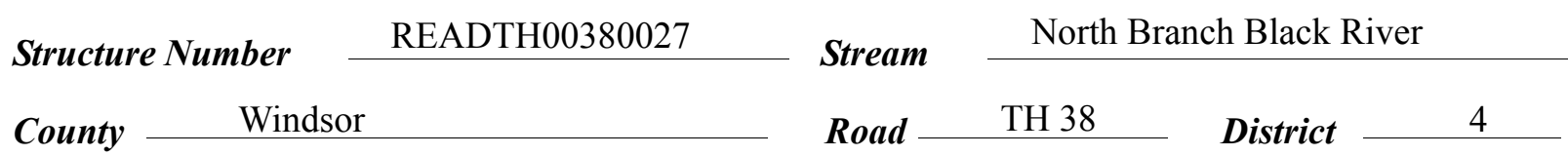

\section{Description of Bridge}

Bridge length $\stackrel{36.0}{ } \boldsymbol{f t}$ Bridge width $\frac{14.0}{f t}$ Max span length $\stackrel{35.0}{ } f t$ Alignment of bridge to road (on curve or straight)

Abutment type Vertical, concrete

Stone fill on abutment?

$$
\text { No }
$$

\section{Embankment type}

Curve

$$
\text { Sloping }
$$

along the entire base length of the upstream left wingwall.

Abutments and wingwalls are concrete. There is a two

ft deep scour hole in front of the left abutment and downstream left wingwall.

The left abutment and downstream left wingwall footing is undermined $1.0 \mathrm{ft}$.

$$
\text { Yes }
$$

Is bridge skewed to flood flow according to Yes ' survey?

Angle

There is a mild_channel bend in the upstream reach.

Debris accumulation on bridge at time of Level I or Level II site visit:

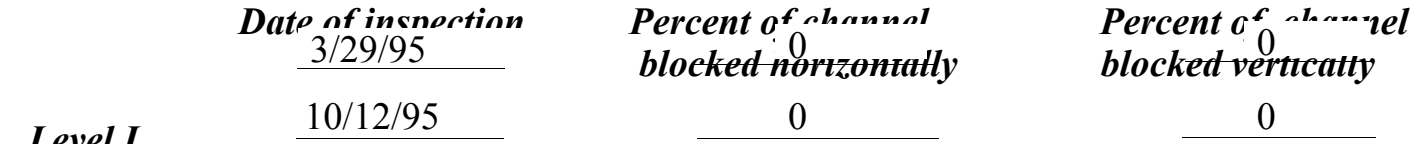

Level I

Moderate. The banks are well vegetated.

Level II

\section{Potential for debris}

None as of 3/29/95.

Doscriho anv fonturos noar ar at tho hridoo that mav, affort flow, (includo ahsorvation dato) 


\section{Description of the Geomorphic Setting}

General topography The channel is located within a moderate relief valley.

Geomorphic conditions at bridge site: downstream (DS), upstream (US)

Date of inspection $\quad 3 / 29 / 95$

DS left: $\quad$ Steep channel bank to an irregular overbank.

DS right: $\quad$ Steep channel bank to a moderately sloped overbank.

US left: $\quad$ Steep channel bank to an overbank.

US right: $\quad$ Steep channel bank to an irregular overbank.

\section{Description of the Channel}

$\begin{array}{llll}\text { Average top width } & 66 & \text { Average depth } & \frac{8}{\text { Gravel/Cobbles }} \\ & \text { Gravel/Cobbles }\end{array}$

Predominant bed material Bank material Sinuous, neither

braided nor anabranched with semi-alluvial channel boundaries.

$3 / 29 / 95$

Vegetative co 1 Trees and brušh.

DS left: $\quad$ Trees and brush.

DS right: $\quad$ Trees and brush.

US left: $\quad$ Trees and brush.

US right:

No

Do banks appear stable? There is moderate to severe fluvial erosion along the upstream and downstream banks.

None as of 3/29/95.

Describe any obstructions in channel and date of observation. 


\section{Hydrology}

Drainage area $\stackrel{9.08}{\mathrm{mi}^{2}}$

Percentage of drainage area in physiographic provinces: (approximate)

Physiographic province/section New England/New England Upland
Percent of drainage area 100
Is drainage area considered rural or urban?
Rural urbanization: None.
Describe any significant

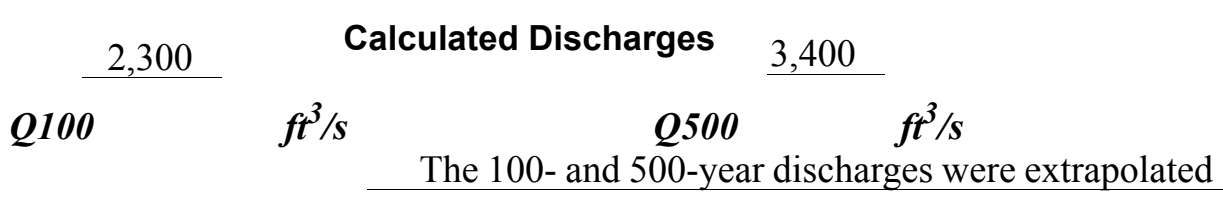

from the values obtained from the VIAOT database for this site. The values used were within a range defined by flood frequency curves developed from several empirical methods (Benson, 1962; Johnson and Tasker, 1974; FHWA, 1983; Potter, 1957a\&b; Talbot, 1887). 


\section{Description of the Water-Surface Profile Model (WSPRO) Analysis}

Datum for WSPRO analysis (USGS survey, sea level, VTAOT plans)

USGS survey

Datum tie between USGS survey and VTAOT plans

None

Description of reference marks used to determine USGS datum. $\quad$ RM1 is a chiseled X on top of the upstream end of the right abutment (elev. $499.90 \mathrm{ft}$, arbitrary survey datum). RM2 is a nail $5 \mathrm{ft}$ high on an oak tree $125 \mathrm{ft}$ upstream and $10 \mathrm{ft}$ left bankward of the left abutment (elev.

$504.75 \mathrm{ft}$, arbitrary survey datum). RM3 is a chiseled X on top of the downstream end of the left abutment (elev. $496.24 \mathrm{ft}$, arbitrary survey datum).

\section{Cross-Sections Used in WSPRO Analysis}

\begin{tabular}{cccl}
\hline${ }^{1}$ Cross-section & $\begin{array}{c}\text { Section } \\
\text { Reference } \\
\text { Distance } \\
(\text { SRD) } \text { in feet }\end{array}$ & $\begin{array}{c}{ }^{2} \text { Cross-section } \\
\text { development }\end{array}$ & \multicolumn{1}{c}{ Comments } \\
\hline EXITA & -147 & 3 & $\begin{array}{l}\text { Exit section(overbanks } \\
\text { added from EXITX) } \\
\text { EXITX }\end{array}$ Exit section $^{\text {Downstream Full-valley }}$ \\
FULLV & 0 & 1 & $\begin{array}{l}\text { section (Templated from } \\
\text { EXITX) }\end{array}$ \\
BRIDG & 0 & 2 & Bridge section \\
RDWAY & 9 & 1 & Road Grade section \\
APPRO & 48 & 1 & Approach section \\
\hline
\end{tabular}

${ }^{1}$ For location of cross-sections see plan-view sketch included with Level I field form, Appendix E. For more detail on how cross-sections were developed see WSPRO input file. 


\section{Data and Assumptions Used in WSPRO Model}

Hydraulic analyses of the reach were done by use of the Federal Highway Administration's WSPRO step-backwater computer program (Shearman and others, 1986, and Shearman, 1990). The analyses reported herein reflect conditions existing at the site at the time of the study. Furthermore, in the development of the model it was necessary to assume no accumulation of debris or ice at the site. Results of the hydraulic model are presented in the Bridge Hydraulic Summary, appendix B, and figure 7.

Channel roughness factors (Manning's " $n$ ") used in the hydraulic model were estimated using field inspections at each cross section following the general guidelines described by Arcement and Schneider (1989). Final adjustments to the values were made during the modelling of the reach. Channel " $n$ " values for the reach ranged from 0.045 to 0.065 , and overbank " $n$ " values ranged from 0.040 to 0.070 .

Critical depth at the downstream exit section (EXITA) was assumed as the starting water surface. Normal depth was computed by use of the slope-conveyance method outlined in the user's manual for WSPRO (Shearman, 1990), and resulted in a supercritical solution. Because normal depth was within $0.2 \mathrm{ft}$ of critical depth, the critical water surface was assumed to be a satisfactory starting water surface. The slope used was $0.030 \mathrm{ft} / \mathrm{ft}$, which was estimated from the topographic map (U.S. Geological Survey, 1972).

The approach section (APPRO) was surveyed one bridge length upstream of the upstream face as recommended by Shearman and others (1986). This location provides a consistent method for determining scour variables. 


\section{Bridge Hydraulics Summary}

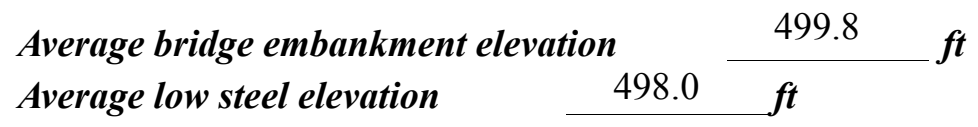

100-year discharge $\quad 2,300 \quad \mathrm{ft}^{3} / \mathrm{s}$

Water-surface elevation in bridge opening $\quad 498.0 \quad f t$

Road overtopping? ___ Yes Discharge over road ___ $209 \mathrm{ft}^{3} / \mathrm{s}$

Area of flow in bridge opening $\quad 203 \quad \mathrm{ft}^{2}$

Average velocity in bridge opening $10.3 \mathrm{ft} / \mathrm{s}$

Maximum WSPRO tube velocity at bridge $20.8 \mathrm{ft} / \mathrm{s}$

Water-surface elevation at Approach section with bridge 501.3

Water-surface elevation at Approach section without bridge $\quad 496.9$

Amount of backwater caused by bridge $\quad 4.4$ it

500-year discharge $\quad 3,400 \quad \mathrm{ft}^{3} / \mathrm{s}$

Water-surface elevation in bridge opening $\quad 498.0 \mathrm{ft}$

Road overtopping? ____ Yes Discharge over road _ $\quad \begin{array}{lll}710 & \mathrm{ft}^{3} / \mathrm{s}\end{array}$

Area of flow in bridge opening $\quad 204 \quad \mathrm{ft}^{2}$

Average velocity in bridge opening $13.2 \mathrm{ft} / \mathrm{s}$

Maximum WSPRO tube velocity at bridge 17.8 's

Water-surface elevation at Approach section with bridge 502.3

Water-surface elevation at Approach section without bridge $\quad 498.0$

Amount of backwater caused by bridge $\quad 4.3, t$

Incipient overtopping discharge $\quad 1,740 \mathrm{ft}^{3} / \mathrm{s}$

Water-surface elevation in bridge opening $498.0 \quad t$

$\begin{array}{lccc}\text { Area of flow in bridge opening } & 204 & \boldsymbol{f t}^{2} \\ \text { Average velocity in bridge opening } & 8.6 & \mathrm{ft} / \mathrm{s}\end{array}$

Maximum WSPRO tube velocity at bridge $11.5 \mathrm{ft} / \mathrm{s}$

Water-surface elevation at Approach section with bridge

Water-surface elevation at Approach section without bridge

499.8

Amount of backwater caused by bridge $\quad 3.7$.t

496.1 


\section{Scour Analysis Summary}

\section{Special Conditions or Assumptions Made in Scour Analysis}

Scour depths were computed using the general guidelines described in Hydraulic Engineering Circular 18 (Richardson and Davis, 1995). Scour depths were calculated assuming an infinite depth of erosive material and a homogeneous particle-size distribution. The results of the scour analyses for the 100- and 500-year discharges are presented in tables 1 and 2 and the scour depths are shown graphically in figure 8 .

At this site, each modeled discharge resulted in orifice flow. Contraction scour at bridges with orifice flow is best estimated by use of the Chang pressure-flow scour equation (oral communication, J. Sterling Jones, October 4, 1996). Thus, contraction scour for these discharges was computed by use of the Chang equation (Richardson and Davis, 1995, p. 145-146). The streambed armoring depths computed suggest that armoring will not limit the depth of contraction scour.

For comparison, contraction scour for the discharges resulting in orifice flow also was computed by use of the Laursen clear-water contraction scour equation (Richardson and Davis, 1995, p. 32, equation 20) and the Umbrell pressure-flow equation (Richardson and Davis, 1995, p. 144). Furthermore, for those discharges resulting in unsubmerged orifice flow, the 100-year and incipient road-overtopping discharges, contraction scour was computed by substituting estimates for the depth of flow at the downstream bridge face in the contraction scour equations. Results with respect to these alternative computations are provided in appendix $\mathrm{F}$.

Abutment scour was computed by use of the Froehlich equation (Richardson and Davis, 1995, p. 48, equation 28). Variables for the Froehlich equation include the Froude number of the flow approaching the embankments, the length of the embankment blocking flow, and the depth of flow approaching the embankment less any roadway overtopping.

The length to depth ratio of the embankment blocking flow exceeded 25 for all modelled discharges at the left abutment and for the 100-year and 500-year discharges at the right abutment. Although the HIRE equation (Richardson and others, 1993, p. 50, equation 25 ) is applicable generally when this ratio exceeds 25 , the results from the HIRE equation were not used. Hydraulic Engineering Circular 18 recommends that field conditions be similar to those from which the HIRE equation was derived (Richardson and others, 1993). Since the equation was developed from U.S. Army Corps. of Engineers' data for spur dikes in the Mississippi River, the HIRE equation was not adopted for the narrow, incised, upland valley at this site. 


\section{Scour Results}

Contraction scour:

Main channel

Live-bed scour

Clear-water scour

Depth to armoring

Left overbank

Right overbank

Local scour:

Abutment scour

Left abutment

Right abutment

Pier scour

Pier 1

Pier 2

Pier 3
14.6

6.9-

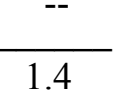

$37.2^{-}$

$-$

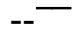

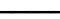

100-year discharge

500-year discharge

(Scour depths in feet)

overtopping discharge 


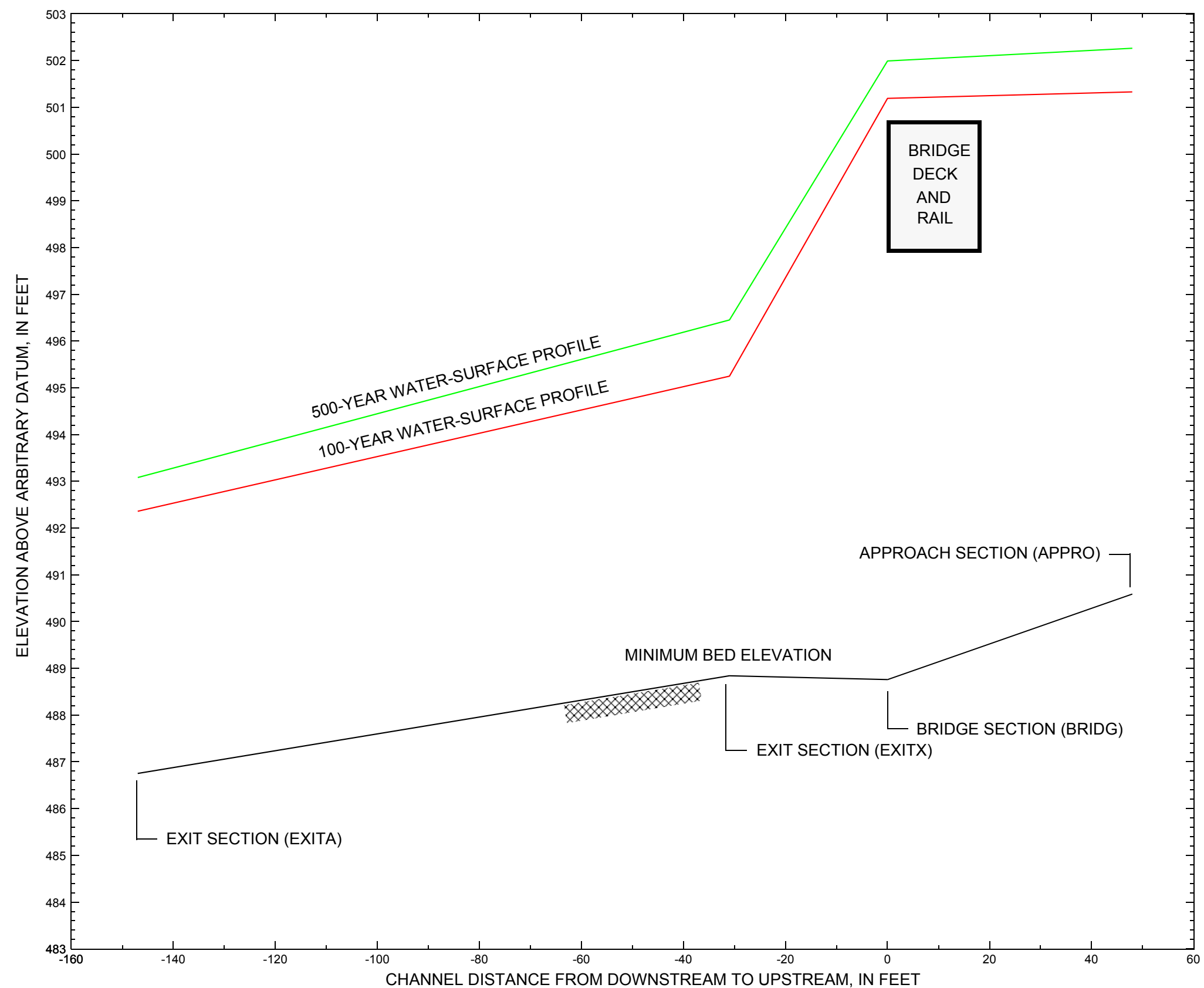

Figure 7. Water-surface profiles for the 100- and 500-year discharges at structure READTH00380027 on Town Highway 38, crossing the North Branch Black River, Reading, Vermont. 


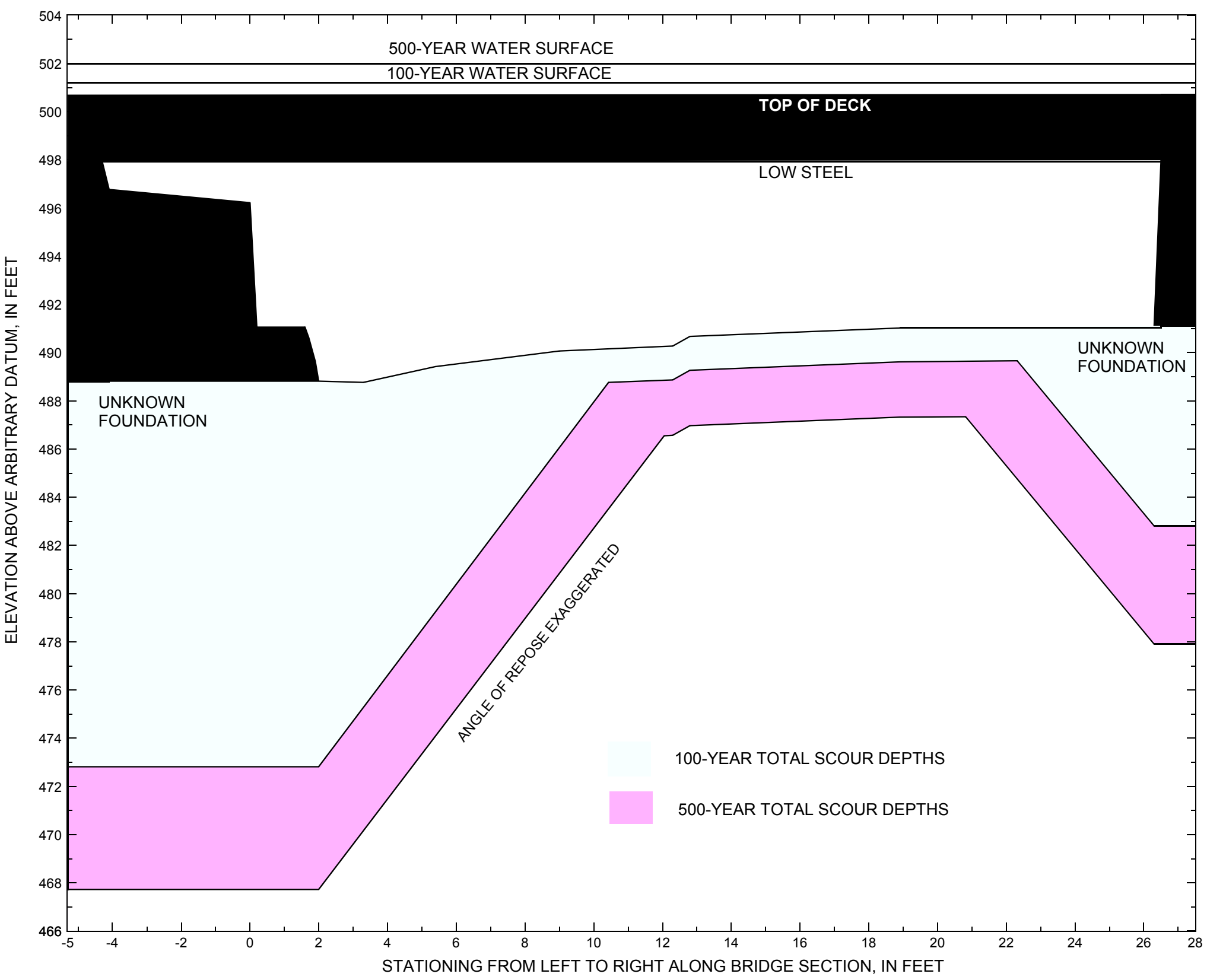

Figure 8. Scour elevations for the 100- and 500-year discharges at structure READTH00380027 on Town Highway 38, crossing the North Branch Black River, Reading, Vermont. 
Table 1. Remaining footing/pile depth at abutments for the 100-year discharge at structure READTH00380027 on Town Highway 38, crossing the North Branch Black River, Reading, Vermont.

[VTAOT, Vermont Agency of Transportation; --, no data]

\begin{tabular}{|c|c|c|c|c|c|c|c|c|c|c|c|}
\hline Description & Station $^{1}$ & $\begin{array}{l}\text { VTAOT } \\
\text { minimum } \\
\text { low-chord } \\
\text { elevation } \\
\text { (feet) }\end{array}$ & $\begin{array}{c}\text { Surveyed } \\
\text { minimum } \\
\text { low-chord } \\
\text { elevation } \\
\text { (feet) }\end{array}$ & $\begin{array}{c}\text { Bottom of } \\
\text { footing/pile } \\
\text { elevation } \\
\text { (feet) }\end{array}$ & $\begin{array}{l}\text { Channel } \\
\text { elevation at } \\
\text { abutment/ } \\
\text { pier }^{2} \\
\text { (feet) }\end{array}$ & $\begin{array}{l}\text { Contraction } \\
\text { scour depth } \\
\text { (feet) }\end{array}$ & $\begin{array}{l}\text { Abutment } \\
\text { scour } \\
\text { depth } \\
\text { (feet) }\end{array}$ & $\begin{array}{l}\text { Pier } \\
\text { scour } \\
\text { depth } \\
\text { (feet) }\end{array}$ & $\begin{array}{l}\text { Depth of } \\
\text { total scour } \\
\text { (feet) }\end{array}$ & $\begin{array}{c}\text { Elevation of } \\
\text { scour }^{2} \\
\text { (feet) }\end{array}$ & $\begin{array}{c}\text { Remaining } \\
\text { footing/pile } \\
\text { depth } \\
\text { (feet) }\end{array}$ \\
\hline \multicolumn{12}{|c|}{100 -year discharge is 2,300 cubic-feet per second } \\
\hline Left abutment & 0.0 & -- & 497.9 & -- & 488.8 & 1.4 & 14.6 & -- & 16.0 & 472.8 & -- \\
\hline Right abutment & 26.5 & -- & 498.0 & -- & 491.1 & 1.4 & 6.9 & -- & 8.3 & 482.8 & -- \\
\hline
\end{tabular}

1.Measured along the face of the most constricting side of the bridge.

2.Arbitrary datum for this study.

Table 2. Remaining footing/pile depth at abutments for the 500-year discharge at structure READTH00380027 on Town Highway 38, crossing the North Branch Black River, Reading, Vermont.

[VTAOT, Vermont Agency of Transportation; --, no data]

\begin{tabular}{|c|c|c|c|c|c|c|c|c|c|c|c|}
\hline Description & Station $^{1}$ & $\begin{array}{l}\text { VTAOT } \\
\text { minimum } \\
\text { low-chord } \\
\text { elevation } \\
\text { (feet) }\end{array}$ & $\begin{array}{c}\text { Surveyed } \\
\text { minimum } \\
\text { low-chord } \\
\text { elevation } \\
\text { (feet) }\end{array}$ & $\begin{array}{c}\text { Bottom of } \\
\text { footing/pile } \\
\text { elevation } \\
\text { (feet) }\end{array}$ & $\begin{array}{c}\text { Channel } \\
\text { elevation at } \\
\text { abutment/ } \\
\text { pier }^{2} \\
\text { (feet) }\end{array}$ & $\begin{array}{l}\text { Contraction } \\
\text { scour depth } \\
\text { (feet) }\end{array}$ & $\begin{array}{c}\text { Abutment } \\
\text { scour } \\
\text { depth } \\
\text { (feet) }\end{array}$ & $\begin{array}{l}\text { Pier } \\
\text { scour } \\
\text { depth } \\
\text { (feet) }\end{array}$ & $\begin{array}{l}\text { Depth of } \\
\text { total scour } \\
\text { (feet) }\end{array}$ & $\begin{array}{c}\text { Elevation of } \\
\text { scour }^{2} \\
\text { (feet) }\end{array}$ & $\begin{array}{c}\text { Remaining } \\
\text { footing/pile } \\
\text { depth } \\
\text { (feet) }\end{array}$ \\
\hline \multicolumn{12}{|c|}{500 -year discharge is 3,400 cubic-feet per second } \\
\hline Left abutment & 0.0 & -- & 497.9 & -- & 488.8 & 3.7 & 17.4 & -- & 21.1 & 467.7 & -- \\
\hline Right abutment & 26.5 & -- & 498.0 & -- & 491.1 & 3.7 & 9.5 & -- & 13.2 & 477.9 & -- \\
\hline
\end{tabular}

1.Measured along the face of the most constricting side of the bridge.

2.Arbitrary datum for this study. 


\section{SELECTED REFERENCES}

Arcement, G.J., Jr., and Schneider, V.R., 1989, Guide for selecting Manning's roughness coefficients for natural channels and flood plains:

U.S. Geological Survey Water-Supply Paper 2339, 38 p.

Barnes, H.H., Jr., 1967, Roughness characteristics of natural channels: U.S. Geological Survey Water-Supply Paper 1849,213 p.

Benson, M. A., 1962, Factors Influencing the Occurrence of Floods in a Humid Region of Diverse Terrain: U.S. Geological Survey WaterSupply Paper 1580-B, 64 p.

Brown, S.A. and Clyde, E.S., 1989, Design of riprap revetment: Federal Highway Administration Hydraulic Engineering Circular No. 11, Publication FHWA-IP-89-016, 156 p.

Federal Emergency Management Agency, 1989, Flood Insurance Study, Town of Reading, Windsor County, Vermont: Washington, D.C., May 4, 1989.

Federal Highway Administration, 1983, Runoff estimates for small watersheds and development of sound design: Federal Highway Administration Report FHWA-RD-77-158.

Federal Highway Administration, 1993, Stream Stability and Scour at Highway Bridges: Participant Workbook: Federal Highway Administration Report FHWA-HI-91-011.

Froehlich, D.C., 1989, Local scour at bridge abutments in Ports, M.A., ed., Hydraulic Engineering--Proceedings of the 1989 National Conference on Hydraulic Engineering: New York, American Society of Civil Engineers, p. 13-18.

Hayes, D.C.,1993, Site selection and collection of bridge-scour data in Delaware, Maryland, and Virginia: U.S. Geological Survey WaterResources Investigation Report 93-4017, 23 p.

Interagency Advisory Committee on Water Data, 1982, Guidelines for determining flood flow frequency: U.S. Geological Survey, Bulletin 17B of the Hydrology Subcommittee, 190 p.

Johnson, C.G. and Tasker, G.D.,1974, Progress report on flood magnitude and frequency of Vermont streams: U.S. Geological Survey OpenFile Report 74-130, 37 p.

Lagasse, P.F., Schall, J.D., Johnson, F., Richardson, E.V., Chang, F., 1995, Stream Stability at Highway Structures: Federal Highway Administration Hydraulic Engineering Circular No. 20, Publication FHWA-IP-90-014, 144 p.

Laursen, E.M., 1960, Scour at bridge crossings: Journal of the Hydraulics Division, American Society of Civil Engineers, v. 86, no. HY2, p. 39-53.

Potter, W. D., 1957a, Peak rates of runoff in the Adirondack, White Mountains, and Maine woods area, Bureau of Public Roads

Potter, W. D., 1957b, Peak rates of runoff in the New England Hill and Lowland area, Bureau of Public Roads

Richardson, E.V. and Davis, S.R., 1995, Evaluating scour at bridges: Federal Highway Administration Hydraulic Engineering Circular No. 18, Publication FHWA-IP-90-017, 204 p.

Richardson, E.V., Simons, D.B., and Julien, P.Y., 1990, Highways in the river environment: Federal Highway Administration Publication FHWA-HI-90-016.

Ritter, D.F., 1984, Process Geomorphology: W.C. Brown Co., Debuque, Iowa, 603 p.

Shearman, J.O., 1990, User's manual for WSPRO--a computer model for water surface profile computations: Federal Highway Administration Publication FHWA-IP-89-027, 187 p.

Shearman, J.O., Kirby, W.H., Schneider, V.R., and Flippo, H.N., 1986, Bridge waterways analysis model; research report: Federal Highway Administration Publication FHWA-RD-86-108, 112 p.

Talbot, A.N., 1887, The determination of water-way for bridges and culverts.

U.S. Geological Survey, 1972, Cavendish, Vermont 7.5 Minute Series quadrangle map: U.S. Geological Survey Topographic Maps, Photoinspected 1983, Scale 1:24,000. 


\section{APPENDIX A: \\ WSPRO INPUT FILE}




\section{WSPRO INPUT FILE}

U.S. Geological Survey WSPRO Input File read027.wsp

Hydraulic analysis for structure READTH00380027 Date: 04-NOV-97

Bridge 27 on Town Highway 38 over N. Branch Black R. Reading, VT MAI

* * 0.002

$62930 \quad 552553551516 \quad 17 \quad 13 \quad 3 * \begin{array}{llllllllll}15 & 14 & 23 & 21 & 11 & 12 & 4 & 7 & 3\end{array}$

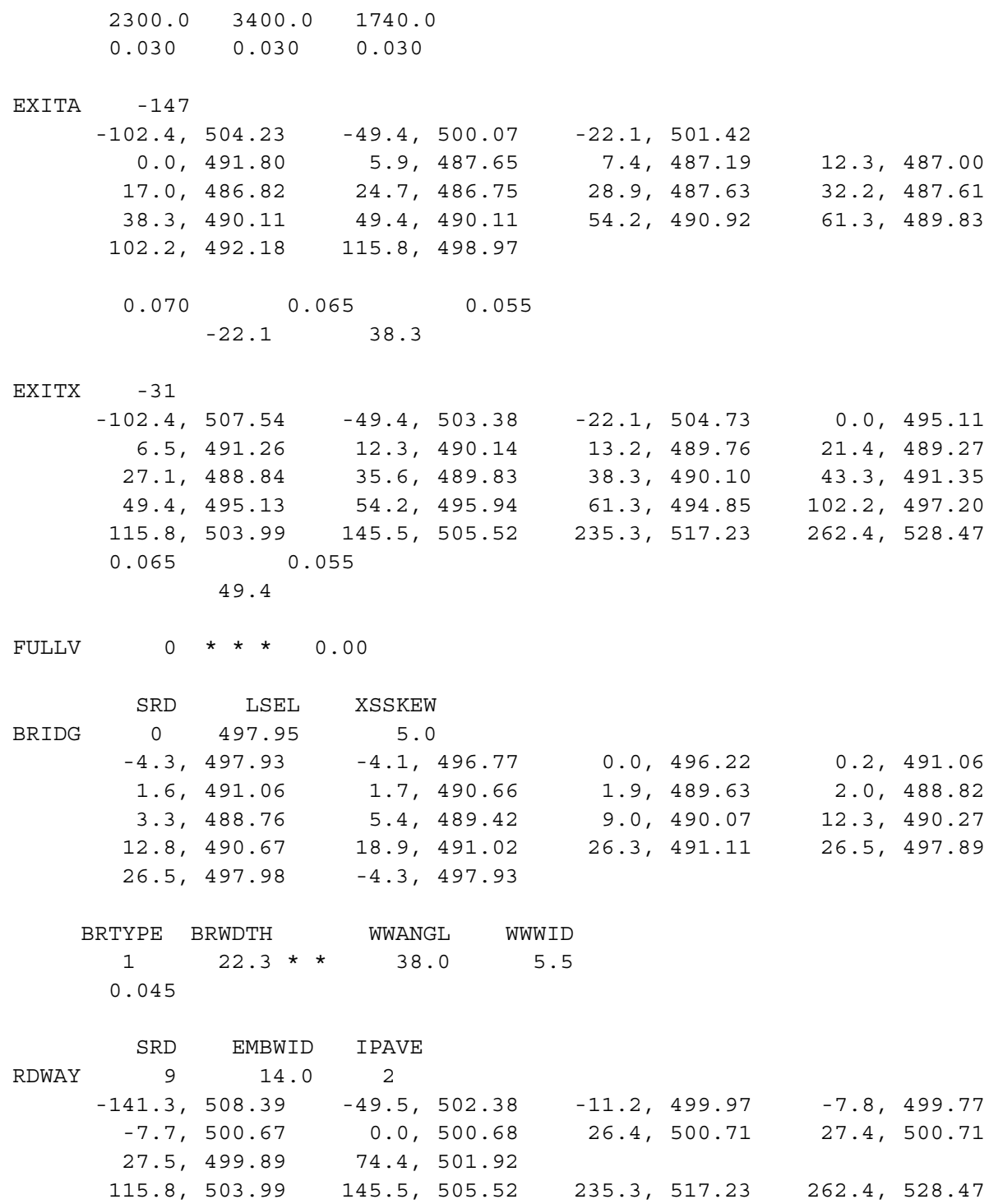




\section{APPENDIX B: \\ WSPRO OUTPUT FILE}




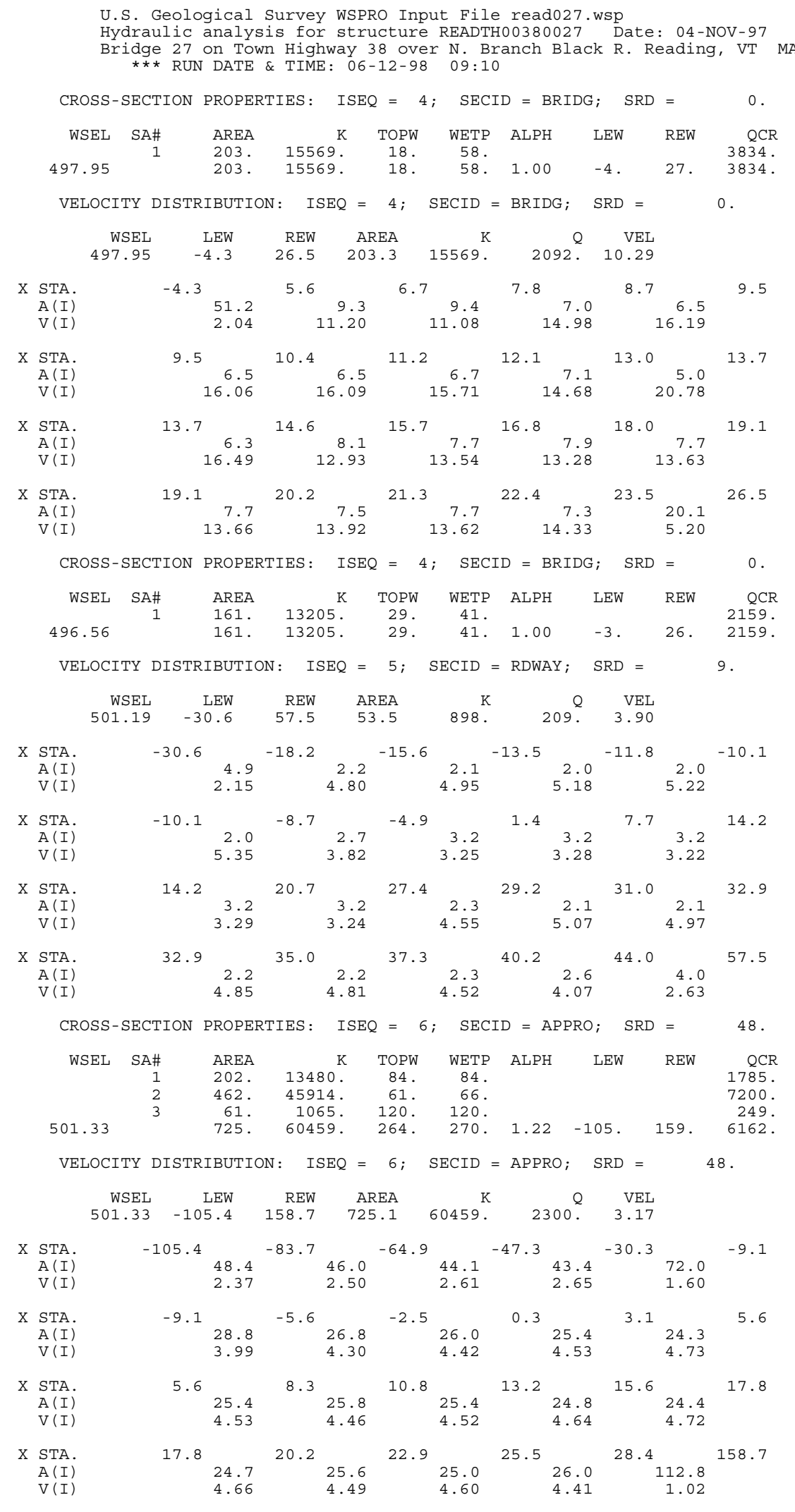




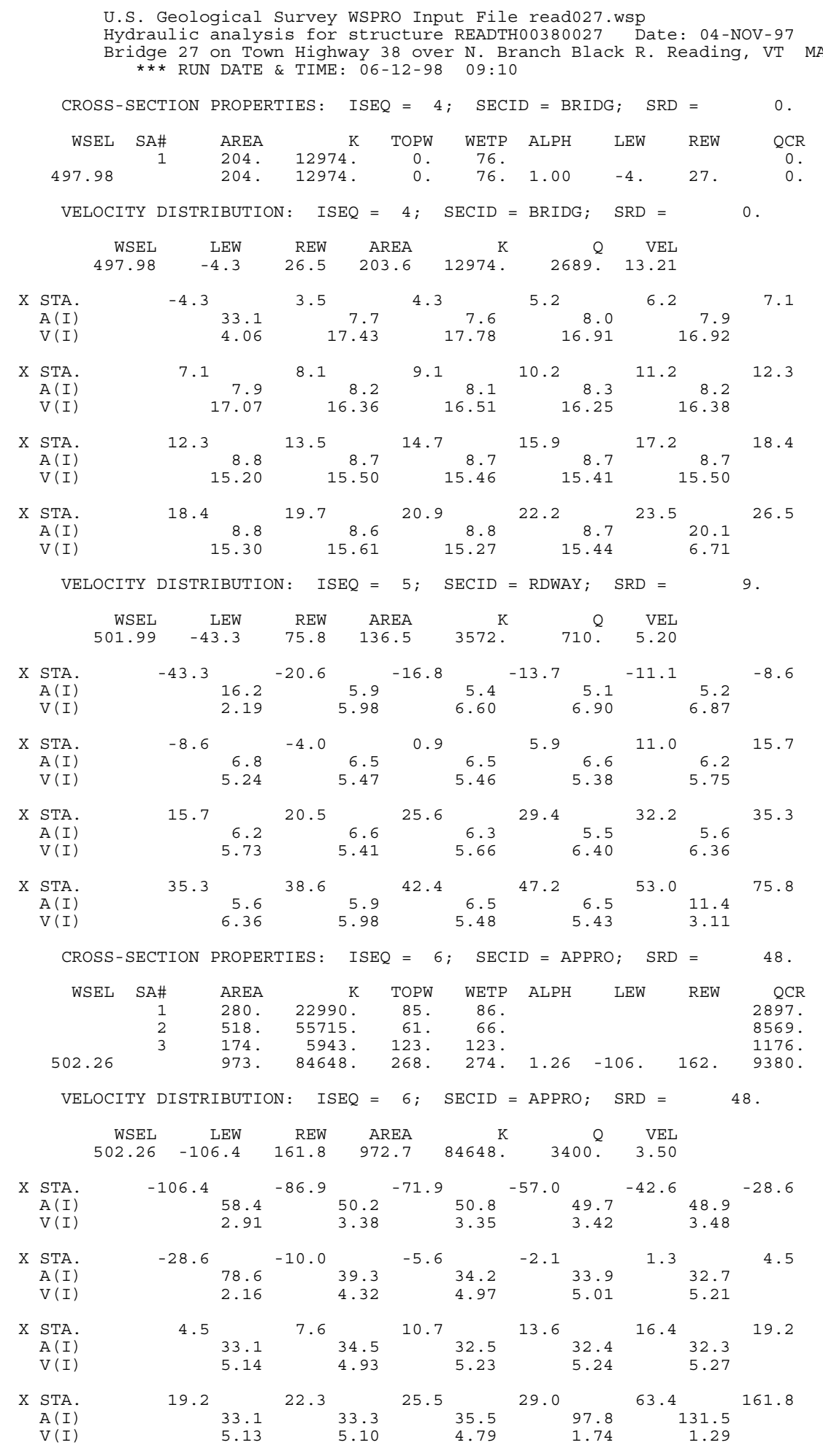


WSPRO OUTPUT FILE (continued)

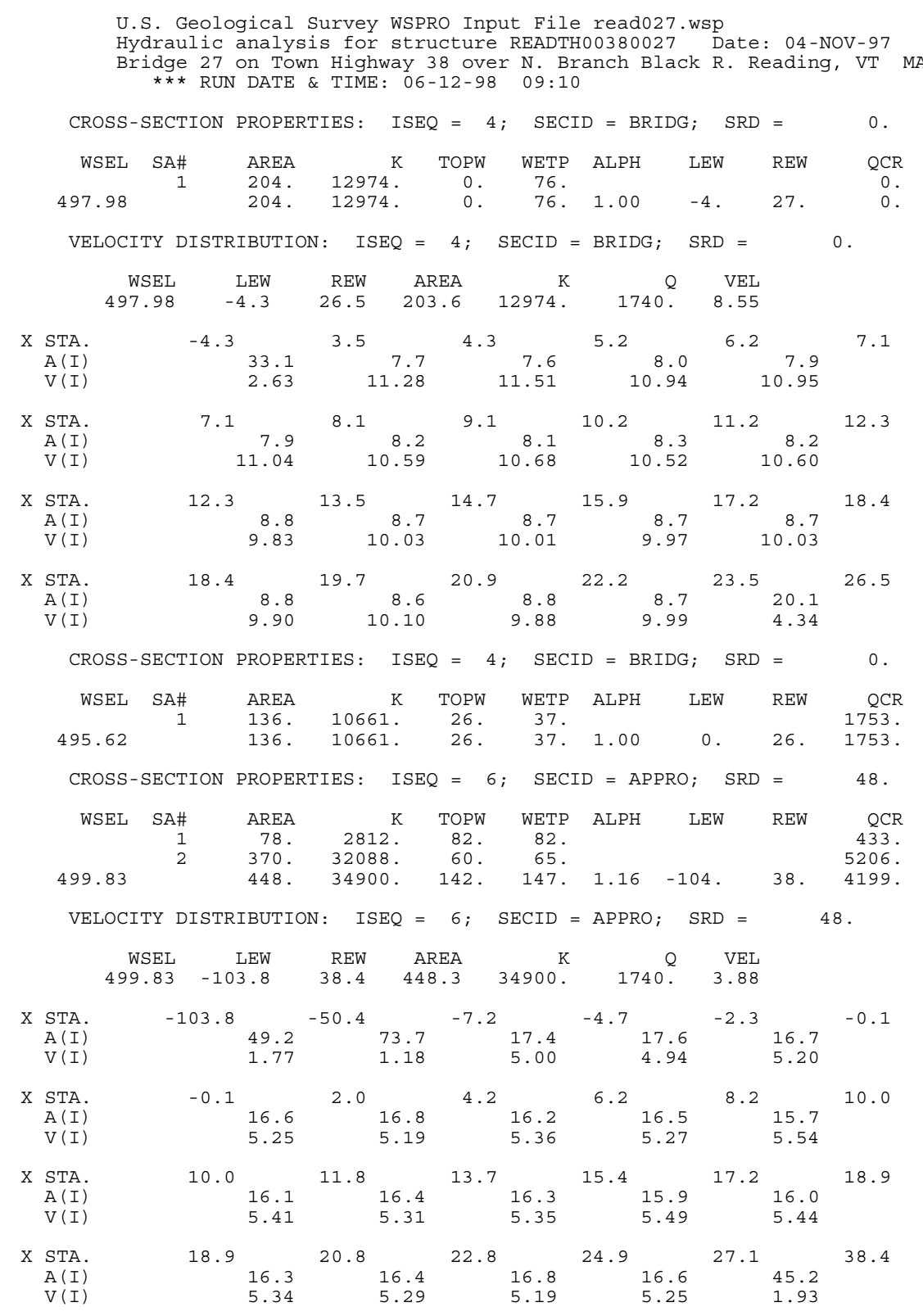


WSPRO OUTPUT FILE (continued)

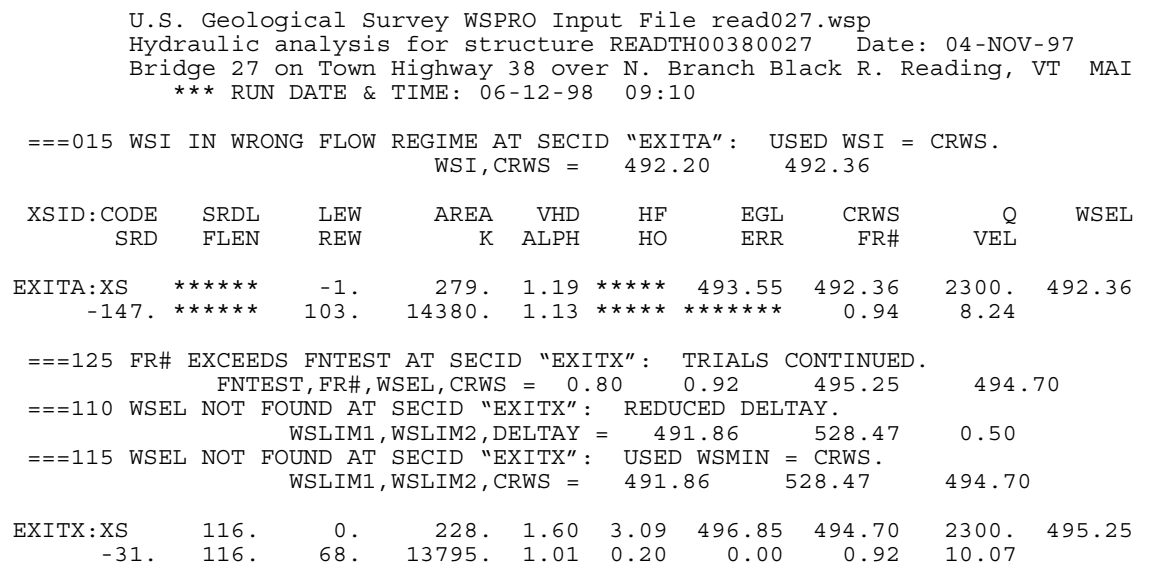

$==135$ CONVEYANCE RATIO OUTSIDE OF RECOMMENDED LIMITS.

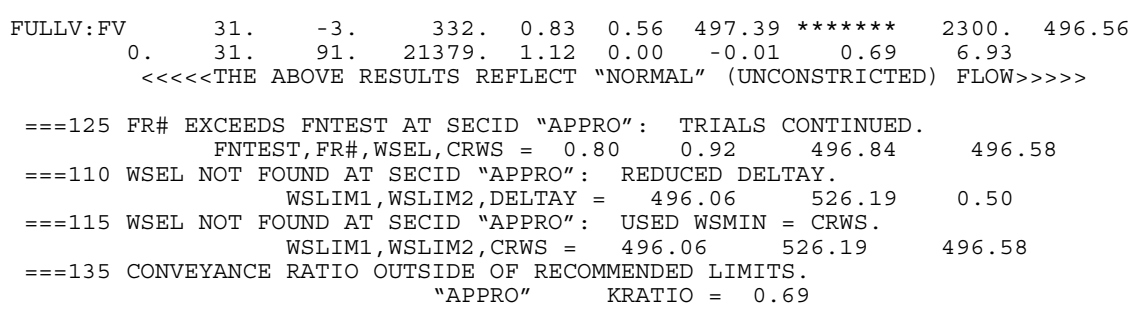

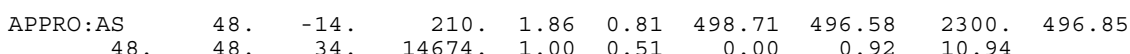
$\ll<<$ THE ABOVE RESULTS REFLECT "NORMAL" (UNCONSTRICTED) FLOW >>>>

$==215$ FLOW CLASS 1 SOLUTION INDICATES POSSIBLE ROAD OVERFLOW. WS1, WSSD, WS 3, RGMIN $=500.16 \quad 0.00 \quad 496.90$

WS1, WSSD, WS3, RGMIN = 500.16
$===260$ ATTEMPTING FLOW CLASS 4 SOLUTION.
$==240$ NO DISCHARGE BALANCE IN 15 ITERATIONS.
WS, QBO, QRD $=504.02$

$==280$ REJECTED FLOW CLASS 4 SOLUTION.

$==245$ ATTEMPTING FLOW CLASS 2 (5) SOLUTION.

o. 2300 .

\section{$<<<<<$ RESULTS REFLECTING THE CONSTRICTED FLOW FOLLOW $>>>>>$}

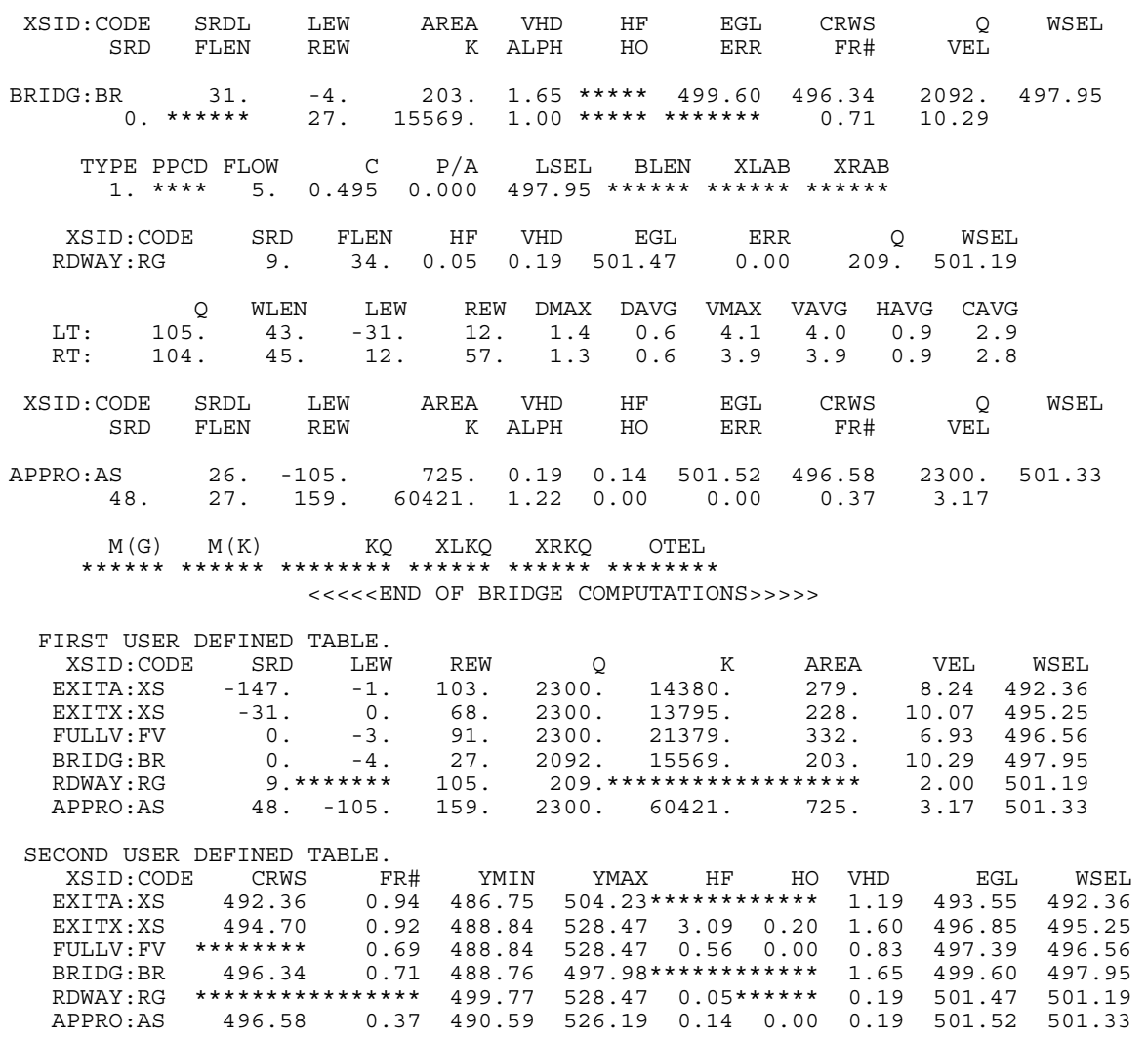


WSPRO OUTPUT FILE (continued)

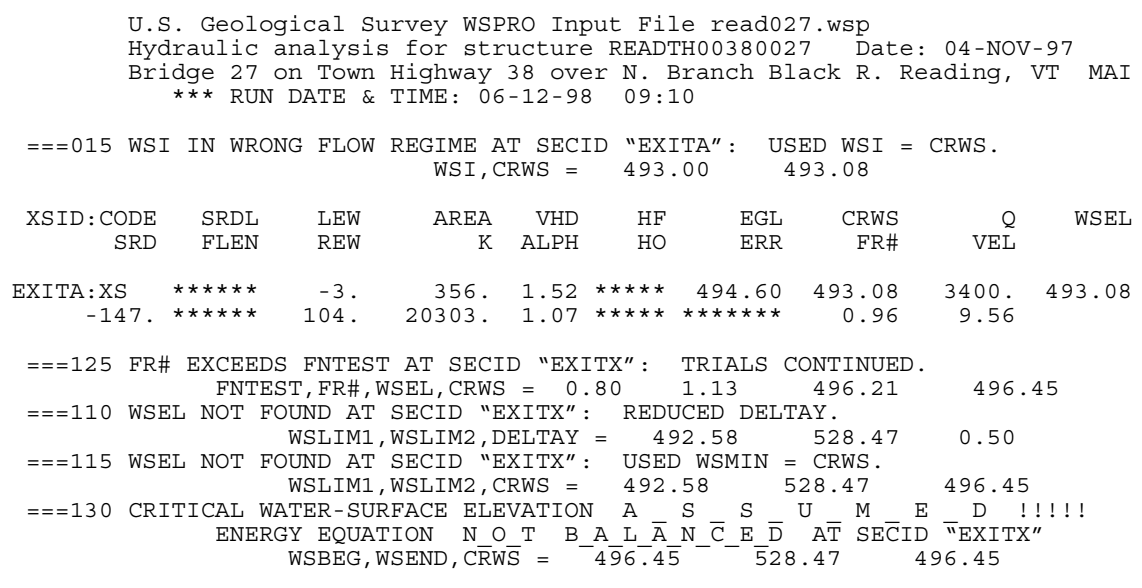
$\begin{array}{rrrrrrrrr}\text { EXITX : XS } & 116 . & -3 . & 322 . & 1.93 * * * * * & 498.38 & 496.45 & 3400 . & 496.45 \\ -31 . & 116 . & 89 . & 20653 . & 1.11 * * * * * * * * * * * & 1.05 & 10.55 & \end{array}$

$===135$ CONVEYANCE RATIO OUTSIDE OF RECOMMENDED LIMITS .

$$
\text { "FULLV" KRATIO }=1.66
$$

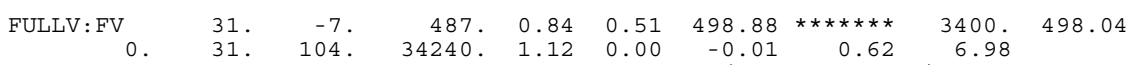

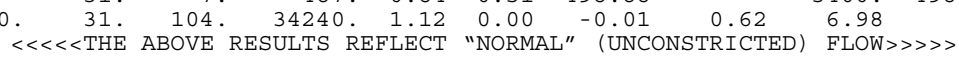

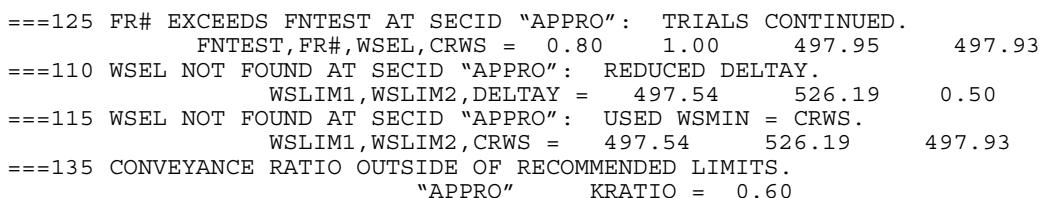

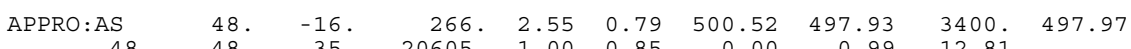

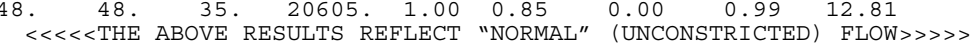

$==255$ ATTEMPTING FLOW CLASS 3 (6) SOLUTION.

$$
\text { WS3N, LSEL }=498.04 \quad 497.95
$$

$<<<<$ RESULTS REFLECTING THE CONSTRICTED FLOW FOLLOW $>>>>>$

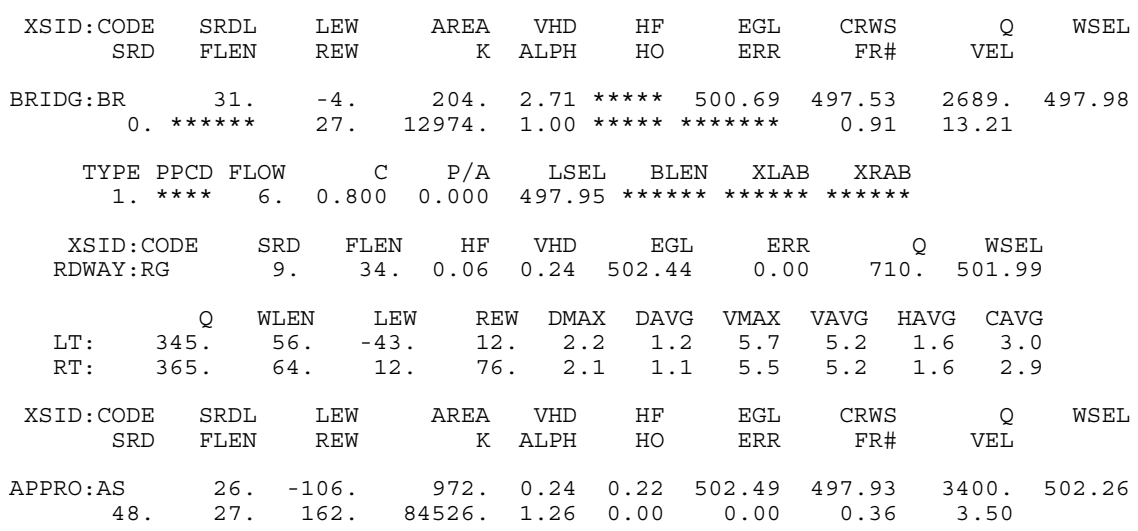

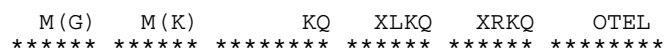

$<<<<$ END OF BRIDGE COMPUTATIONS $>>>>>$

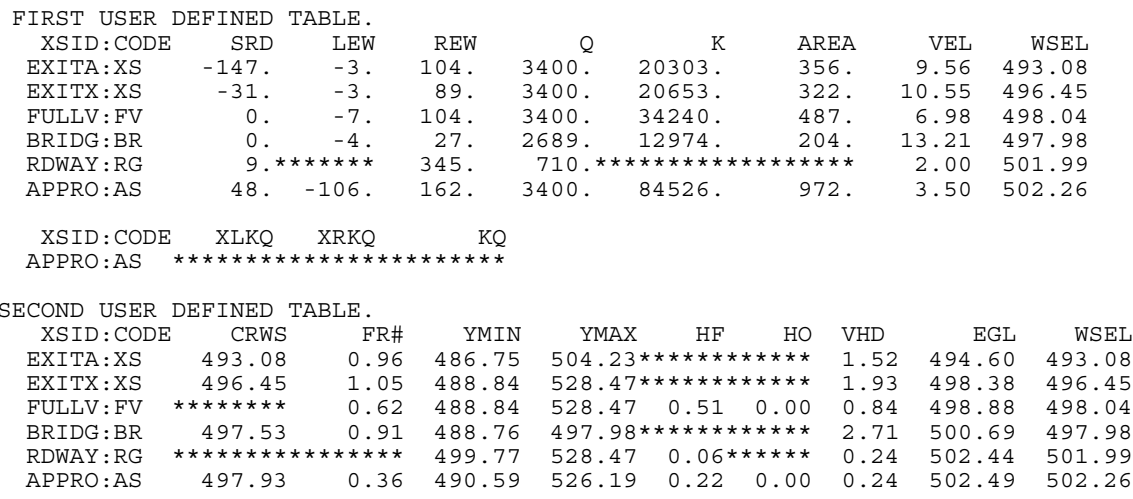


WSPRO OUTPUT FILE (continued)

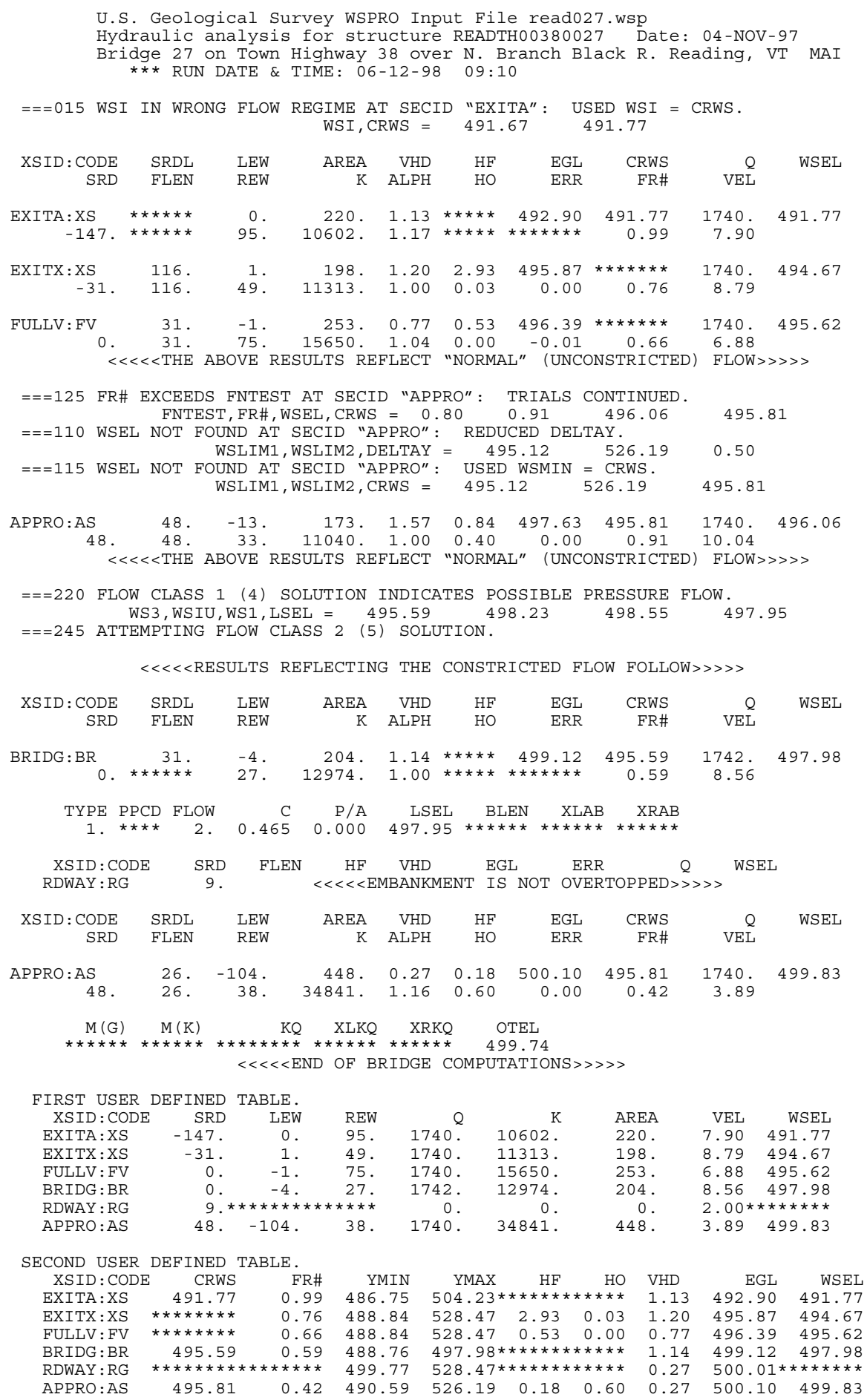




\section{APPENDIX C:}

\section{BED-MATERIAL PARTICLE-SIZE DISTRIBUTION}




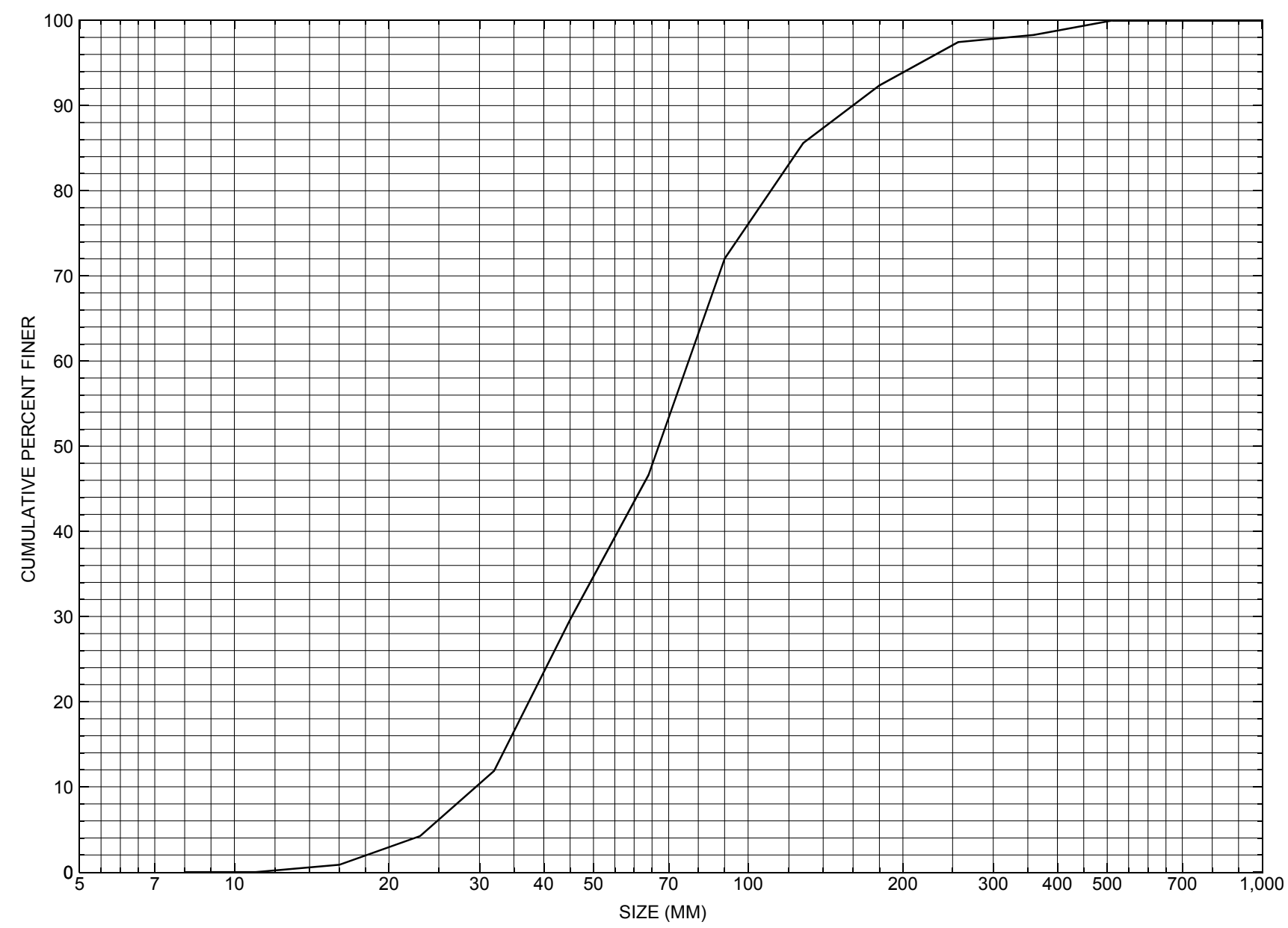

Appendix C. Bed material particle-size distribution for a pebble count in the channel approach of structure READTH00380027, in Reading, Vermont. 


\section{APPENDIX D: \\ HISTORICAL DATA FORM}




\section{Structure Number READTH00380027}

\section{General Location Descriptive}

Data collected by (First Initial, Full last name) $\underline{\mathbf{E}}$. Boehmler

Date $(M M / D D / Y Y) \_\mathbf{0 3} / \underline{09} / \underline{95}$

Highway District Number (I - 2; nn) $\mathbf{0 4}$

Town (FIPS place code; I - 4; nnnnn) $\mathbf{5 8 3 7 5}$

Waterway (I - 6) North Branch Black River

Route Number $\mathbf{T H 0 3 8}$

Topographic Map Cavendish

Latitude (I - 16; nnnn.n) $\mathbf{4 3 2 8 2}$
County (FIPS county code; I - 3; nnn)

Mile marker (I - 11; nnn.nnn) $\mathbf{0 0 0 0 0 0}$

Road Name (I - 7): -

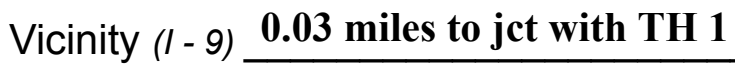

Hydrologic Unit Code: $\mathbf{0 1 0 8 0 1 0 6}$

Longitude (i - 17; nnnnn.n) $\mathbf{7 2 3 4 2}$

\section{Select Federal Inventory Codes}

FHWA Structure Number (I - 8) 10141400271414

Maintenance responsibility $(I-21 ; n n) \quad \mathbf{0 3}$

Year built (I - 27; YYYY) 1974

Average daily traffic, ADT (I - 29; nnnnnn) 000010

Year of ADT (I - 30; YY) $\mathbf{9 1}$

Opening skew to Roadway $(I-34 ; n n) \quad \mathbf{1 0}$

Operational status $(I-41 ; X) \quad \mathbf{P}$

Structure type (I- 43; nnn) $\mathbf{3 0 2}$

Approach span structure type (I - 44; nnn) $\mathbf{0 0 0}$

Number of spans (I - 45; nnn) $\underline{\mathbf{0 0 1}}$

Number of approach spans (I - 46; nnnn) $\mathbf{0 0 0 0}$

Comments:

The structural inspection report of 9/10/93 indicates the structure is a steel stringer type bridge with a timber deck. The right abutment is concrete. The right abutment is in good condition with no exposure of the footing or cracking of the concrete noted. The report indicated that nearly 3 years ago the left abutment stone wall was faced with concrete and a concrete subfooting was constructed. The subfooting is undermined $1 \mathrm{ft}$ by an adjacent scour hole. The concrete facing and subfooting show no signs of settling. The waterway makes a sharp turn through the structure and impacts the left abutment. There is some heavy stream bank erosion just upstream from the left abutment. The report indicates that scour is likely to continue along the left abutment with the current channel alignment. 


\section{Bridge Hydrologic Data}

Is there hydrologic data available? $\underline{\mathbf{N}}$ if No, type ctrl- $n$ VTAOT Drainage area $\left(\mathrm{mi}^{2}\right)$ : -

Terrain character:

Stream character \& type: -

Streambed material: Stone and gravel with some random boulders.

Discharge Data (cfs): $\quad \mathrm{Q}_{2.33}$

$$
\mathrm{Q}_{50}
$$

Record flood date (MM / DD / YY): -

Estimated Discharge (cfs): Ice conditions (Heavy, Moderate, Light) : -

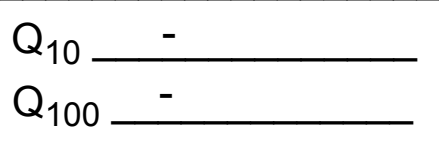

$$
Q_{25}-
$$

Water surface elevation (ft): -

Velocity at $Q$ $(\mathrm{ft} / \mathrm{s}):$

The stage increases to maximum highwater elevation (Rapidly, Not rapidly):

The stream response is (Flashy, Not flashy):

Describe any significant site conditions upstream or downstream that may influence the stream's stage: -

Watershed storage area (in percent): - _ \%

The watershed storage area is: - (1-mainly at the headwaters; 2- uniformly distributed; 3-immediatly upstream oi the site)

Water Surface Elevation Estimates for Existing Structure:

\begin{tabular}{|l|l|l|l|l|l|}
\hline Peak discharge frequency & $Q_{2.33}$ & $Q_{10}$ & $Q_{25}$ & $Q_{50}$ & $Q_{100}$ \\
Water surface elevation (ft)) & - & - & - & - & - \\
Velocity (ft/sec) & - & - & - & - & - \\
\hline
\end{tabular}

Long term stream bed changes: -

Is the roadway overtopped below the $\mathrm{Q}_{100}$ ? (Yes, No, Unknown): $\mathbf{U} \quad$ Frequency: Relief Elevation (ft): Discharge over roadway at $\mathrm{Q}_{100}\left(\mathrm{ft}^{3} / \mathrm{sec}\right)$ :

Are there other structures nearby? (Yes, No, Unknown): $\underline{\mathbf{U}}$ Upstream distance (miles): Town: If No or Unknown, type ctrl-n os Highway No. : Structure No. :Year Built:

Clear span (ft): Clear Height (ft): Full Waterway $\left(f^{2}\right)$ : 
Downstream distance (miles): Town: Year Built:

Highway No. : Structure No. : Structure Type:

Clear span (ft): Clear Height $(f t)$ : Full Waterway $\left(f^{2}\right)$ : -

Comments:

\section{USGS Watershed Data}

Watershed Hydrographic Data

Drainage area (DA) $\mathbf{9 . 0 8}$

Watershed storage (ST) $\mathrm{mi}^{2}$ Lake/pond/swamp area 0.09 $\mathrm{mi}^{2}$

Bridge site elevation Main channel length 1103 $\mathrm{ft}$ $\%$ $10 \%$ channel length elevation mi

Headwater elevation 2478 $\mathrm{ft}$

$4.16 \mathrm{mi}$

Main channel slope $(S)$

(S) 173.24 1240 $\mathrm{ft} \quad 85 \%$ channel length elevation 1780 $\mathrm{ft}$

Watershed Precipitation Data

Average site precipitation in Average headwater precipitation in

Maximum 2yr-24hr precipitation event $(124,2)$ in

Average seasonal snowfall (Sn) $\mathrm{ft}$ 


\section{Bridge Plan Data}

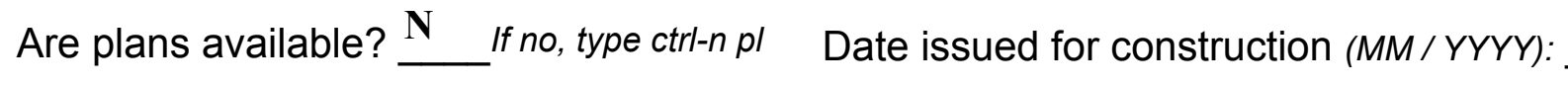

Project Number

Minimum channel bed elevation:

Low superstructure elevation: USLAB DSLAB USRAB DSRAB Benchmark location description:

NO BENCHMARK INFORMATION

Reference Point (MSL, Arbitrary, Other): Datum (NAD27, NAD83, Other):

Foundation Type: 4

If 1 : Footing Thickness

If 2: Pile Type:

If 3: Footing bottom elevation:

Is boring information available? $\mathbf{N}$

Foundation Material Type: $\mathbf{3}$

(1-Spreadfooting; 2-Pile; 3- Gravity; 4-Unknown)

Footing bottom elevation: -

Briefly describe material at foundation bottom elevation or around piles:

NO FOUNDATION MATERIAL INFORMATION 


\section{Cross-sectional Data}

Is cross-sectional data available? Yes If no, type ctrl-n xs

Source (FEMA, VTAOT, Other)? VTAOT

Comments: The station and low chord to bed differences are taken from a sketch dated 9/10/93 of the upstream face that was attached to a bridge inspection report. The low chord elevation is an average of the coordinates surveyed during the level 2 assessment on 10/12/95.

\begin{tabular}{|l|l|l|l|l|l|l|l|l|l|l|l|}
\hline Station & $\mathbf{0}$ & $\mathbf{1 . 5 0}$ & $\mathbf{1 . 5 1}$ & $\mathbf{1 7 . 5 0}$ & $\mathbf{3 5 . 0 0}$ & - & - & - & - & - & - \\
\hline Feature & LAB & - & - & - & RAB & - & - & - & - & - & - \\
\hline $\begin{array}{l}\text { Low chord } \\
\text { elevation }\end{array}$ & $\mathbf{4 9 7 . 9 5}$ & $\mathbf{4 9 7 . 9 5}$ & $\mathbf{4 9 7 . 9 5}$ & $\mathbf{4 9 7 . 9 5}$ & $\mathbf{4 9 7 . 9 5}$ & - & - & - & - & - & - \\
\hline $\begin{array}{l}\text { Bed } \\
\text { elevation }\end{array}$ & $\mathbf{4 9 1 . 0 5}$ & $\mathbf{4 9 1 . 0 5}$ & $\mathbf{4 8 8 . 8 2}$ & $\mathbf{4 9 0 . 6 2}$ & $\mathbf{4 9 0 . 9 5}$ & - & - & - & - & - & - \\
\hline $\begin{array}{l}\text { Low chord } \\
\text { to bed }\end{array}$ & $\mathbf{6 . 9 0}$ & $\mathbf{6 . 9 0}$ & $\mathbf{9 . 1 3}$ & $\mathbf{7 . 3 3}$ & $\mathbf{7}$ & - & - & - & - & - & - \\
\hline Station & - & - & - & - & - & - & - & - & - & - & - \\
\hline Feature & - & - & - & - & - & - & - & - & - & - & - \\
\hline $\begin{array}{l}\text { Low chord } \\
\text { elevation }\end{array}$ & - & - & - & - & - & - & - & - & - & - & - \\
\hline $\begin{array}{l}\text { Bed } \\
\text { elevation }\end{array}$ & - & - & - & - & - & - & - & - & - & - & - \\
\hline $\begin{array}{l}\text { Low chord } \\
\text { to bed }\end{array}$ & - & - & - & - & - & - & - & - & - & - & - \\
\hline
\end{tabular}

Source (FEMA, VTAOT, Other)?

Comments: -

\begin{tabular}{|l|l|l|l|l|l|l|l|l|l|l|l|}
\hline Station & - & - & - & - & - & - & - & - & - & - & - \\
\hline Feature & - & - & - & - & - & - & - & - & - & - & - \\
\hline $\begin{array}{l}\text { Low chord } \\
\text { elevation }\end{array}$ & - & - & - & - & - & - & - & - & - & - & - \\
\hline $\begin{array}{l}\text { Bed } \\
\text { elevation }\end{array}$ & - & - & - & - & - & - & - & - & - & - & - \\
\hline $\begin{array}{l}\text { Low chord } \\
\text { to bed }\end{array}$ & - & - & - & - & - & - & - & - & - & - & - \\
\hline Station & - & - & - & - & - & - & - & - & - & - & - \\
\hline Feature & - & - & - & - & - & - & - & - & - & - & - \\
\hline $\begin{array}{l}\text { Low chord } \\
\text { elevation }\end{array}$ & - & - & - & - & - & - & - & - & - & - & - \\
\hline $\begin{array}{l}\text { Bed } \\
\text { elevation }\end{array}$ & - & - & - & - & - & - & - & - & - & - & - \\
\hline $\begin{array}{l}\text { Low chord } \\
\text { to bed }\end{array}$ & - & - & - & - & - & - & - & - & - & - & - \\
\hline
\end{tabular}




\section{APPENDIX E: \\ LEVEL I DATA FORM}


U. S. Geological Survey

Bridge Field Data Collection and Processing Form

Qa/Qc Check by: EW Date: $6 / 96$

\section{Structure Number}

READTH00380027

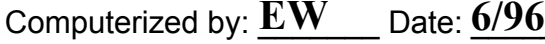

Reviewd by: MAI Date: $\underline{\mathbf{1 / 3 0 / 9 8}}$

\section{A. General Location Descriptive}

1. Data collected by (First Initial, Full last name) M WEBER

2. Highway District Number 04

Mile marker 000000

County WINDSOR (027)

Waterway (I - 6) N. BRANCH BLACK RIVER

Route Number $\mathbf{T H O 3 8}$

Town READING (58375)

Road Name ARCHER ROAD

Hydrologic Unit Code: $\mathbf{0 1 0 8 0 1 0 6}$

3. Descriptive comments:

The bridge is located 0.03 miles from the junction with VT 100. A passerby said the old bridge went out in 1967.

\section{B. Bridge Deck Observations}
4. Surface cover... LBUS 6
RBUS 5
LBDS 6
RBDS 6
Overall 6

(2b us,ds,lb,rb: 1- Urban; 2- Suburban; 3- Row crops; 4- Pasture; 5- Shrub- and brushland; 6- Forest; 7- Wetland)
5. Ambient water surface... US 1
UB 1
DS 1
(1- pool; 2- riffle)

6. Bridge structure type 1 (1- single span; 2- multiple span; 3- single arch; 4- multiple arch; 5-cylindrical culvert; 6- box culvert; or 7- other)
7. Bridge length $\mathbf{3 6}$
(feet)
Span length $\mathbf{3 5}$
(feet)
Bridge width 14.0 (feet)

\section{Road approach to bridge:}
8. LB 2
RB 2
( 0 even, 1- lower, 2- higher)
9. LB_
RB $\underline{2}$
(1-Paved, 2- Not paved)

10. Embankment slope (run / rise in feet / foot)

US left

US right

\begin{tabular}{|c|c|c|c|}
\hline \multicolumn{2}{|c|}{ Protection } & \multirow{2}{*}{ 13.Erosion } & 14.Severity \\
\hline 11.Type & 12.Cond. & $\mathbf{0}$ & $\mathbf{0}$ \\
\hline $\mathbf{1}$ & $\mathbf{1}$ & $\mathbf{0}$ & $\mathbf{0}$ \\
\hline $\mathbf{1}$ & $\mathbf{1}$ & $\mathbf{0}$ & $\mathbf{0}$ \\
$\mathbf{2}$ & $\mathbf{1}$ & $\mathbf{0}$ \\
\hline $\mathbf{1}$ & $\mathbf{1}$ & $\mathbf{0}$ & $\mathbf{0}$ \\
\hline
\end{tabular}

Bank protection types: 0- none; 1- < 12 inches;

2- $<36$ inches; $3-<48$ inches;

4- < 60 inches; 5- wall / artificial levee

Bank protection conditions: 1- good; 2- slumped;

3- eroded; 4- failed

Erosion: 0 - none; 1- channel erosion; 2 -

road wash; 3- both; 4- other

Erosion Severity: 0 - none; 1- slight; 2- moderate; 3- severe

\section{Channel approach to bridge (BF):}

15. Angle of approach: $\mathbf{4 0}$

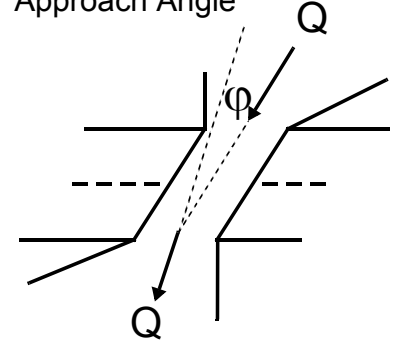

17. Channel impact zone 1 :

Where? RB (LB, RB)

Range? 80 feet US

Channel impact zone 2:

Where? LB $(L B, R B)$

Range? 10 feet $\underline{\mathbf{U S}}$

Impact Severity: 0- none to very slight; 1- Slight; 2- Moderate; 3- Severe
16. Bridge skew: $\mathbf{5 0}$ Bridge Skew Angle

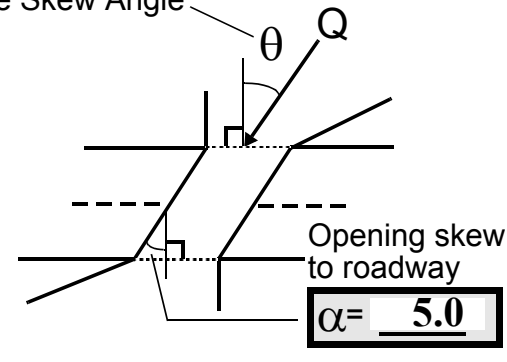

\section{Exist? $\underline{\mathbf{Y}}(\mathrm{Y}$ or $N)$}

Severity $\underline{3}$

, UB, DS) to 130 feet $\mathbf{U S}$

Severity 2

$U B, D S)$ to $\underline{\mathbf{0} \quad \text { feet }} \underline{\mathbf{D S}}$
Exist? $\underline{\mathbf{Y}}(\mathrm{Y}$ or $N)$ 
18. Bridge Type: 1a

1a- Vertical abutments with wingwalls

1 b- Vertical abutments without wingwalls

2- Vertical abutments and wingwalls, sloping embankment Wingwalls parallel to abut. face

3- Spill through abutments

4- Sloping embankment, vertical wingwalls and abutments

Wingwall angle less than $90^{\circ}$.

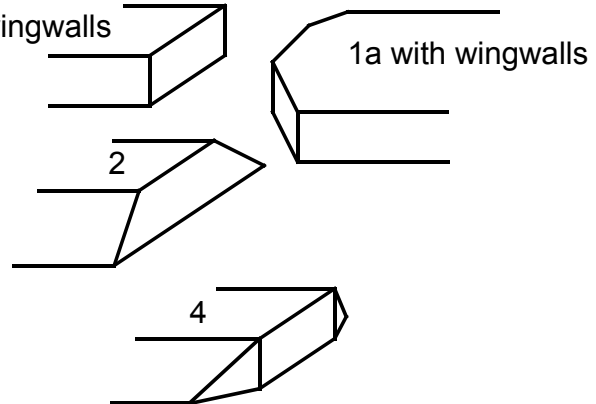

19. Bridge Deck Comments (surface cover variations, measured bridge and span lengths, bridge type variations, approach overflow width, etc.)

\#4: The LBUS is a sparsely wooded forest. The RBUS has grass adjacent to the stream and a road with brushland and forest beyond. The LBDS is a forest except for an area 10-20 feet DS. The RBDS surface cover is the same as the LBDS

\#7: Values are from VTAOT. During site visit, the measured bridge length was 36.5 feet, the span length was 31 feet, and the bridge width was 14.0 feet.

\#11: The USRB has the most extensive road approach protection coverage.

\section{Upstream Channel Assessment}

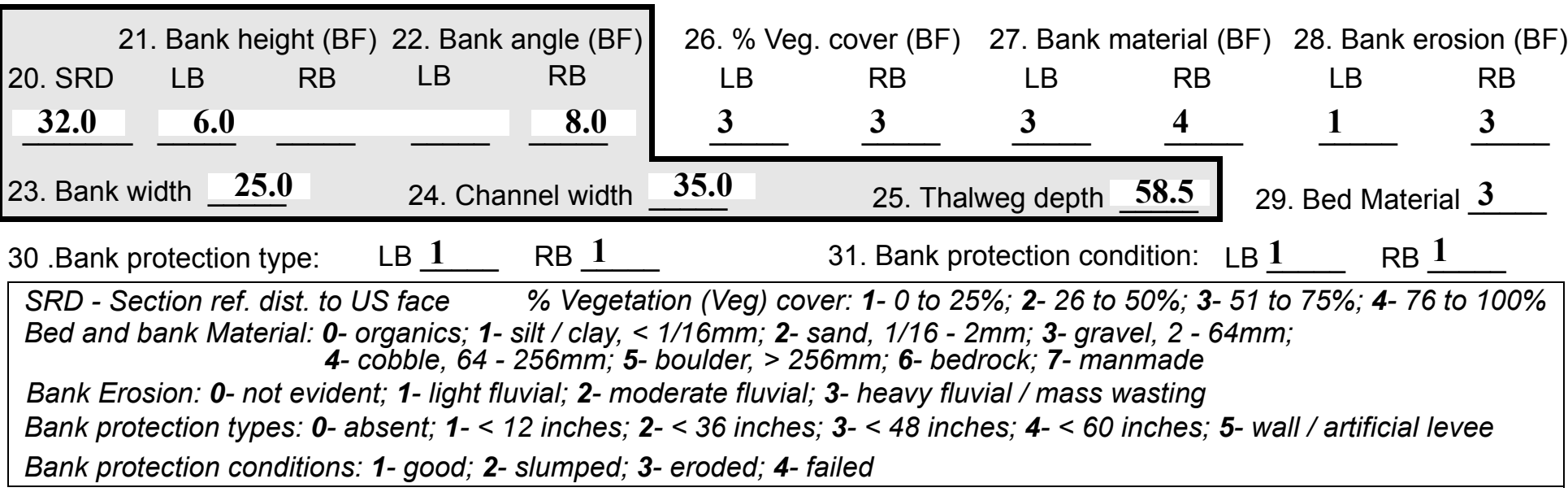

32. Comments (bank material variation, minor inflows, protection extent, etc.):

\#26: The right bank vegetation cover is less dense upstream of bridge.

\#27: The right bank material from the upstream bridge face to 100 feet US is cobble, gravel and boulder. In the area of 120 feet US, the right bank material is clay with gravel. The left bank material is gravel and sand with some boulders.

\#28: On the left bank, there is light fluvial erosion just US of the bridge and just DS of the US point bar. The US reach is characterized by lateral instability, another point bar/cut bank combination exists just US of the cut bank and point bar visible from the bridge.

\#29: The bed material is composed of gravel, cobble, sand and scattered boulders.

\#30: The left bank protection extends from 0 to 25 feet US and is placed native cobble and boulder. Some bank erosion has occurred despite the protection. 

feet $\underline{\mathbf{U S}}$ (US, UB, DS) positioned $\mathbf{0}$ $\%$ LB to 60 $\%$ RB

37. Material: 1

38. Point or side bar comments (Circle Point or Side; Note additional bars, material variation, status, etc.):

The point bar material is silt, sand, gravel, cobble and some boulders. There is brushy vegetation growing on the bar.

39. Is a cut-bank present? $\mathbf{Y}$ (Y or if $N$ type ctrl-n cb) 40. Where? $\underline{\mathbf{R B}}$ (LB or RB)

41. Mid-bank distance: 100 42.

43. Bank damage: 1 (1- eroded and/or creep; 2- slip failure; 3- block failure)

44. Cut bank comments (eg. additional cut banks, protection condition, etc.):

-

45. Is channel scour present? $\mathbf{N}$ (Y or if $N$ type ctrl-n cs)

47. Scour dimensions: Length Width Depth : 46. Mid-scour distance: -

48. Scour comments (eg. additional scour areas, local scouring process, etc.):

NO CHANNEL SCOUR

49. Are there major confluences? $\mathbf{N}$

51. Confluence 1: Distance Confluence 2: Distance 52. Enters on Enters on 54. Confluence comments (eg. confluence name):

NO MAJOR CONFLUENCES
50. How many? -

53. Type(1- perennial; 2- ephemeral)

Type (1-perennial; 2- ephemeral) ( $(L B$ or $R B)$ (LB or $R B)$

\section{Under Bridge Channel Assessment}

55. Channel restraint (BF)? LB 2

\begin{tabular}{|ccccc|}
\hline \multicolumn{2}{|c}{ 56. Height (BF) } & \multicolumn{3}{c}{57 Angle (BF) } \\
LB & RB & & LB & RB \\
$\mathbf{3 6 . 0}$ & & & $\mathbf{1 . 0}$ & \\
\hline
\end{tabular}
(1- natural bank; 2- abutment; 3- artificial levee)

58. Bank width (BF) -

59. Channel width -

\begin{tabular}{lc} 
61. Material (BF) \\
LB & RB \\
$\mathbf{2}$ & $\mathbf{7}$ \\
\hline
\end{tabular}

61. Material (BF)

7
62. Erosion (BF)

LB RB

7

Bed and bank Material: 0- organics; 1- silt / clay, < 1/16mm; 2- sand, 1/16 - 2mm; 3- gravel, 2 - 64mm; 4- cobble, 64 - 256mm; 5- boulder, > 256mm; 6- bedrock; 7- manmade

Bank Erosion: 0- not evident; 1- light fluvial; 2- moderate fluvial; 3- heavy fluvial / mass wasting

64. Comments (bank material variation, minor inflows, protection extent, etc.):

345

\#63 The bed material is gravel, cobble, sand and scattered boulders.

There is a gap in the DS lower end of the left abutment stonework where culvert flow would enter the stream. A culvert passes under the left road approach and drains the US left overbank. There is no flow through the culvert at this time. 
65. Debris and Ice Is there debris accumulation?

$(Y$ or $N)$ 66. Where? $\mathbf{N}$

(1- Upstream; 2- At bridge; 3-Both)

67. Debris Potential ( 1- Low; 2- Moderate; 3- High)

68. Capture Efficiency 2

(1- Low; 2- Moderate; 3- High)

69. Is there evidence of ice build-up? 1 (Y or $N)$

Ice Blockage Potential $\mathbf{N}$

(1-Low; 2-Moderate; 3- High)

70. Debris and Ice Comments:

1

Lateral migration US may cause trees to be undercut and fall into the channel. The bridge will not constrict bank full flow.

\begin{tabular}{|l|c|c|c|c|c|c|c|c|}
\hline Abutments & $\begin{array}{c}71 . \text { Attack } \\
\angle \text { (BF) }\end{array}$ & $\begin{array}{c}72 \text {. Slope } \angle \\
\text { (Qmax) }\end{array}$ & $\begin{array}{c}\text { 73. Toe } \\
\text { loc. (BF) }\end{array}$ & $\begin{array}{c}\text { 74. Scour } \\
\text { Condition }\end{array}$ & $\begin{array}{c}75 . \text { Scour } \\
\text { depth }\end{array}$ & $\begin{array}{c}\text { 76. Exposure } \\
\text { depth }\end{array}$ & 77. Material & 78. Length \\
\hline LABUT & & $\mathbf{4 0}$ & $\mathbf{9 0}$ & $\mathbf{2}$ & $\mathbf{3}$ & $\mathbf{2}$ & $\mathbf{3}$ & $\mathbf{9 0 . 0}$ \\
\hline RABUT & $\mathbf{1}$ & - & $\mathbf{9 0}$ & & & $\mathbf{2}$ & $\mathbf{0}$ & $\mathbf{3 0 . 5}$ \\
\hline
\end{tabular}

Pushed: $L B$ or RB

Toe Location (Loc.): 0- even, 1- set back, 2- protrudes

Scour cond.: 0- not evident; 1- evident (comment); 2- footing exposed; 3-undermined footing; 4- piling exposed; 5- settled; 6- failed

Materials: 1- Concrete; 2- Stone masonry or drywall; 3- steel or metal; 4- wood

79. Abutment comments (eg. undermined penetration, unusual scour processes, debris, etc.):

$-$

1

The left abutment footing is exposed 3 feet above the channel bottom almost its entire length, though at the US end, the exposure depth is $\mathbf{1 . 5}$ feet. As noted in historical form, the left abutment is a stonewall which was faced with concrete and an additional subfooting. The undermined penetration is 1 foot.

80. Wingwalls: $\begin{array}{llll} & & & \\ \text { Exist? Material? } & \text { Scour } & \text { Scour } & \text { Exposure } \\ \text { Condition? } & \text { depth? } & \text { depth? }\end{array}$

USLWW:
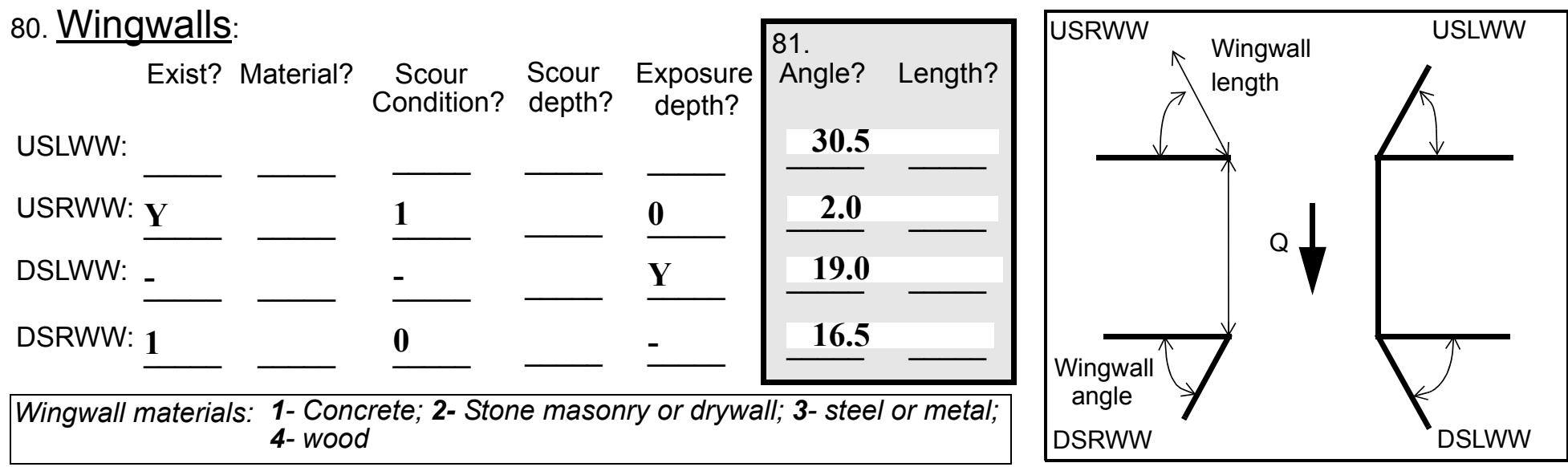

82. Bank / Bridge Protection:

\begin{tabular}{|l|l|l|l|l|l|l|l|l|}
\hline Location & USLWW & USRWW & LABUT & RABUT & LB & RB & DSLWW & DSRWW \\
\hline Type & - & $\mathbf{3}$ & $\mathbf{Y}$ & - & $\mathbf{1}$ & $\mathbf{1}$ & - & - \\
\hline Condition & $\mathbf{Y}$ & $\mathbf{2}$ & $\mathbf{1}$ & - & $\mathbf{1}$ & $\mathbf{2}$ & - & - \\
\hline Extent & $\mathbf{1}$ & $\mathbf{2}$ & $\mathbf{0}$ & $\mathbf{2}$ & $\mathbf{2}$ & $\mathbf{0}$ & $\mathbf{0}$ & - \\
\hline
\end{tabular}

Bank / Bridge protection types: 0- absent; 1- < 12 inches; 2- < 36 inches; 3- < 48 inches; 4- < 60 inches; 
83. Wingwall and protection comments (eg. undermined penetration, unusual scour processes, etc.):

-
-
-
-
-
0
-
-
0
-
-

\section{Piers:}

84. Are there piers? Co (Y or if $N$ type ctrl-n pr)

\begin{tabular}{|l|l|r|r|l|l|l|l|}
\hline \multirow{2}{*}{$\begin{array}{l}85 . \\
\text { Pier no. }\end{array}$} & \multicolumn{3}{|c|}{ width (w) feet } & \multicolumn{3}{c|}{ elevation (e) feet } \\
\cline { 2 - 9 } & w1 & w2 & w3 & e@w1 & e@w2 & e@w3 \\
\hline Pier 1 & & $\mathbf{4 . 0}$ & & $\mathbf{3 5 . 0}$ & $\mathbf{4 0 . 0}$ & $\mathbf{1 0 . 5}$ \\
\hline Pier 2 & & $\mathbf{5 . 0}$ & $\mathbf{8 . 0}$ & $\mathbf{8 0 . 0}$ & $\mathbf{1 0 5 . 0}$ & - \\
\hline Pier 3 & - & - & - & - & - & - \\
\hline Pier 4 & - & - & - & - & - & - \\
-
\end{tabular}

\begin{tabular}{|l|l|l|l|l|}
\hline Level 1 Pier Descr. & \multicolumn{1}{|c|}{1} & \multicolumn{1}{|c|}{2} & \multicolumn{1}{|c|}{3} & \multicolumn{1}{|c|}{4} \\
\hline 86. Location (BF) & verage & ; the & Type-2 & UT are \\
\hline 87. Type & at & pro- & stone & not \\
\hline 88. Material & the & tec- & s & con- \\
\hline 89. Shape & upst & tion & that & sid- \\
\hline 90. Inclined? & ream & exte & are & ered \\
\hline 91. Attack $\angle$ (BF) & end & nds & part & as \\
\hline 92. Pushed & of & US & of & pro- \\
\hline 93. Length (feet) & - & - & - & - \\
\hline 94. \# of piles & the & as & the & tec- \\
\hline 95. Cross-members & USR & bank & old & tion. \\
\hline 96. Scour Condition & WW & pro- & dry & \\
\hline 97. Scour depth & is & tec- & wall & \\
\hline 98. Exposure depth & light & tion. & LAB & \\
\hline
\end{tabular}

LFP, LTB, LB, MCL, MCM, MCR, RB, RTB, RFP

1- Solid pier, 2-column, 3- bent

1-Wood; 2- concrete; 3- metal; 4- stone

1- Round; 2- Square; 3- Pointed

Y-yes; $N-$ no

$L B$ or $R B$

0- none; 1- laterals; 2- diagonals; 3- both

0- not evident; 1- evident (comment);

2- footing exposed; 3- piling exposed;

4- undermined footing; 5- settled; 6- failed 
99. Pier comments (eg. undermined penetration, protection and protection extent, unusual scour processes, etc.):

$\mathbf{N}$

$-$

$-$

$-$

100.

\section{E. Downstream Channel Assessment}

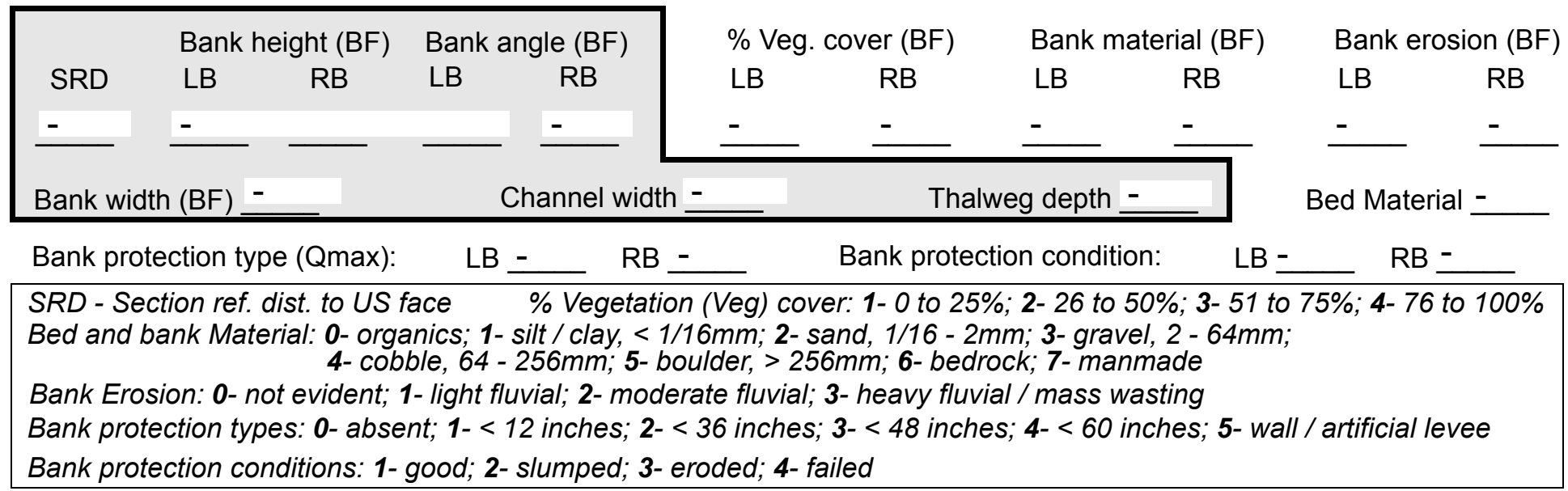

Comments (eg. bank material variation, minor inflows, protection extent, etc.):

$-$

$-$

$-$

$-$

$-$

-

-

-

-

-

-

-

-

-

101. Is a drop structure present? _ ( _ or N, if $N$ type ctrl-n ds) 102. Distance: ___ feet
103. Drop: - feet
104. Structure material: -
(1- steel sheet pile; 2- wood pile; 3- concrete; 4- other)

105. Drop structure comments (eg. downstream scour depth):

$-$

$-$

-

-

-

$-$ 
106. Point/Side bar present? (Y or N. if N type ctrl-n pb)Mid-bar distance: Mid-bar width: -

Point bar extent: feet (US, UB, DS) to feet (US, UB, DS) positioned $\%$ LB to $\% \mathrm{RB}$ Material:

Point or side bar comments (Circle Point or Side; note additional bars, material variation, status, etc.):

NO PIERS

Is a cut-bank present?

Cut bank extent: feet (US, UB, DS) to (Y or if $N$ type ctrl-n cb) Where? (LB or $R B)$

Mid-bank distance:

Bank damage: 4 (1-eroded and/or creep; 2- slip failure; 3- block failure)

Cut bank comments (eg. additional cut banks, protection condition, etc.): 4

3

3

3

Is channel scour present? 2 ( 2 or if $N$ type ctrl-n cs) Mid-scour distance: $\mathbf{3}$ Scour dimensions: Length 1 Width $\underline{1}$ Depth: 1 Positioned 1 _L LB to The $\%$ RB Scour comments (eg. additional scour areas, local scouring process, etc.):

re is an area on both banks 10-20 feet DS that is cleared of trees. The bank material is gravel, sand, cobble and boulder. Along the cut area of the left bank, the sand is washed away. At 250 feet DS on the LB, there exists clay with gravel which is exposed, similar to the upstream right bank material. Bed material is gravel, cobble, sand and boulder. There is natural cobble and boulder protection, but from 0 to 80 feet DS on the left Are there major confluences? ba (Yor if $N$ type ctrl-n $m c$ ) How many? nk Confluence 1: Distance and Confluence 2: Distance to 35 Enters on fro $(L B$ or $R B)$ Type $\mathbf{m} 0$ (1- perennial; 2- ephemeral) Confluence comments (eg. confluence name):

on the right bank the material looks as though it was placed by man. There is moderate fluvial erosion on the right bank downstream of the protection and light fluvial erosion on the left bank concurrent with the protec-

\section{F. Geomorphic Channel Assessment}

107. Stage of reach evolution tio

1- Constructed

2- Stable

3- Aggraded

4- Degraded

5- Laterally unstable

6- Vertically and laterally unstable 
108. Evolution comments (Channel evolution not considering bridge effects; See HEC-20, Figure 1 for geomorphic descriptors):

n. Severe cutting is seen on the left bank further downstream.

$\mathbf{N}$

$-$

NO DROP STRUCTURE 


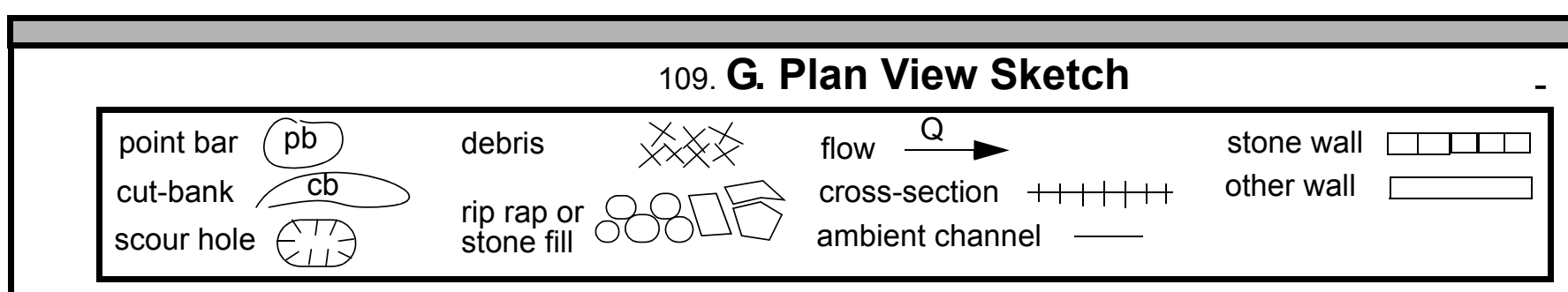


APPENDIX F:

SCOUR COMPUTATIONS 


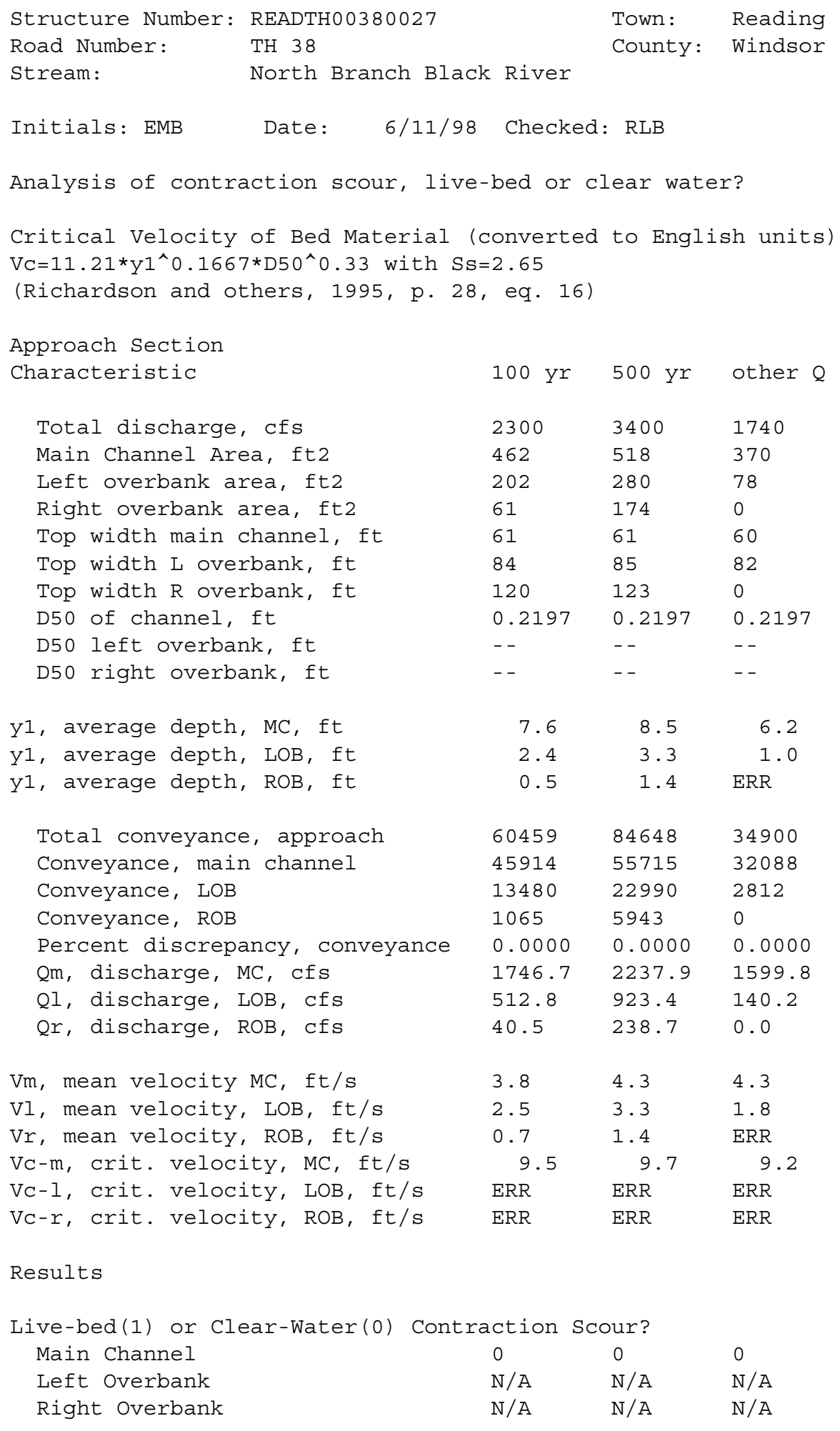




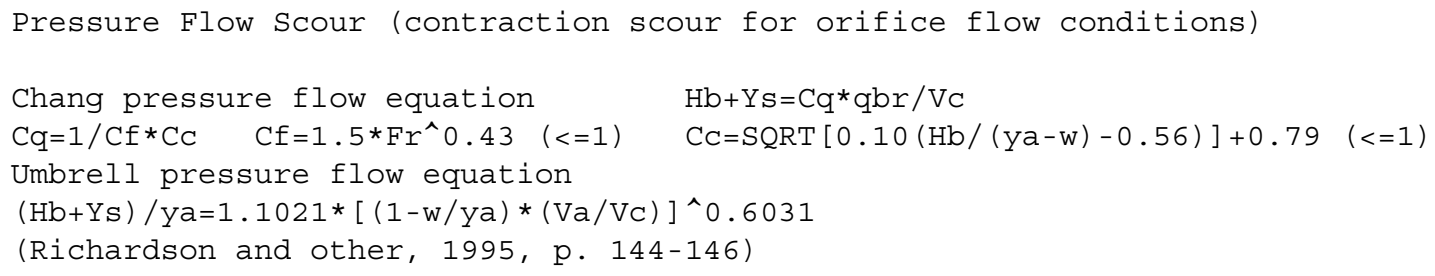


Clear water Contraction Scour in MAIN CHANNEL

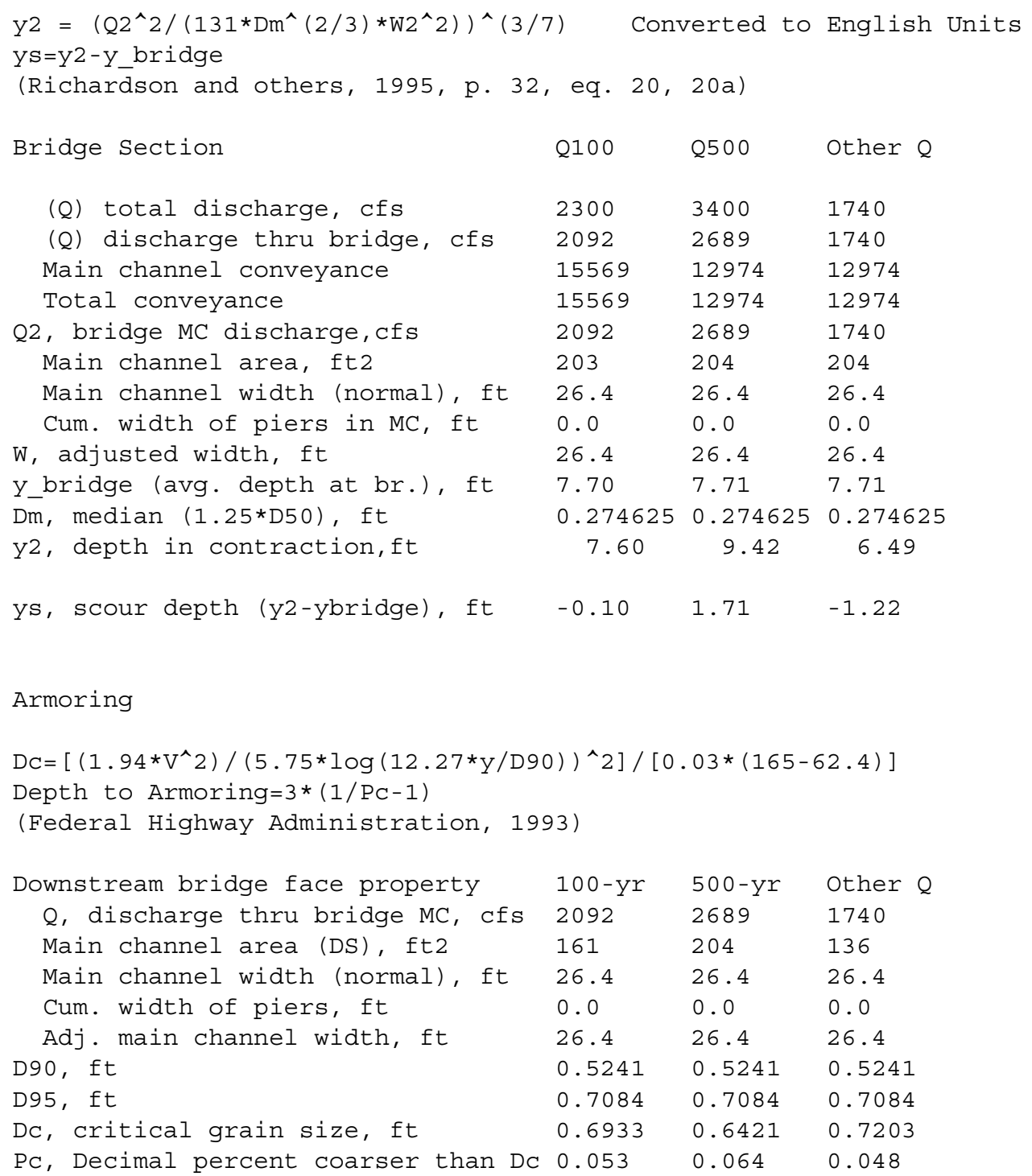




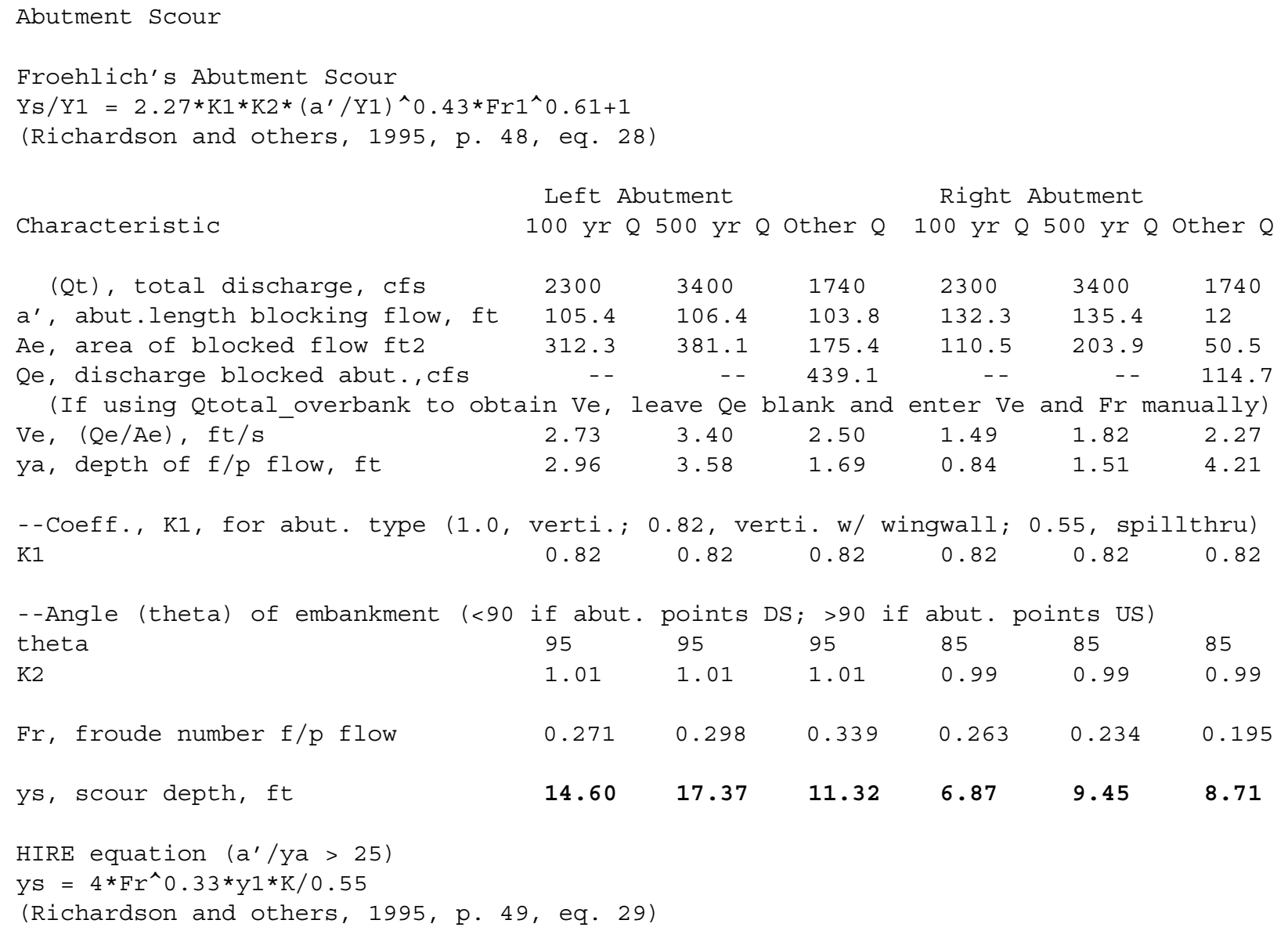




\begin{tabular}{|c|c|c|c|c|c|c|}
\hline$a^{\prime}$ (abut length blocked, ft) & 105.4 & 106.4 & 103.8 & 132.3 & 135.4 & 12 \\
\hline y1 (depth f/p flow, ft) & 2.96 & 3.58 & 1.69 & 0.84 & 1.51 & 4.21 \\
\hline$a^{\prime} / y 1$ & 35.57 & 29.71 & 61.43 & 158.40 & 89.91 & 2.85 \\
\hline Skew correction (p. 49, fig. 16) & 1.01 & 1.01 & 1.01 & 0.98 & 0.98 & 0.98 \\
\hline Froude no. f/p flow & 0.27 & 0.30 & 0.34 & 0.26 & 0.23 & 0.20 \\
\hline Ys w/ corr. factor $\mathrm{K} 1 / 0.55$ : & 14.15 & 1764 & 8.69 & 3.83 & 6.65 & ERR \\
\hline vertical w/ ww's & 11.60 & 14.47 & 7.13 & 3.14 & 5.45 & ERR \\
\hline spill-through & 7.78 & 9.70 & 4.78 & 2.11 & 3.66 & ERR \\
\hline Abutment riprap Sizing & & & & & & \\
\hline Isbash Relationship & & & & & & \\
\hline $\begin{array}{l}\mathrm{D} 50=\mathrm{Y}^{*} \mathrm{~K} * \mathrm{Fr} \mathrm{r}^{\wedge} 2 /(\mathrm{Ss}-1) \text { and } \mathrm{D} 50=\mathrm{Y}^{*} \mathrm{~K} *( \\
\text { (Richardson and others, 1995, p11 }\end{array}$ & $\begin{array}{l}\wedge 2)^{\wedge} 0.1 \\
\text { eq. } 81\end{array}$ & $(S s-1)$ & & & & \\
\hline Characteristic & Q100 & Q500 & Other $Q$ & Q100 & Q500 & Other $\mathrm{Q}$ \\
\hline Fr, Froude Number & 0.93 & 0.91 & 0.99 & 0.93 & 0.91 & 0.99 \\
\hline y, depth of flow in bridge, ft & 6.10 & 7.71 & 5.15 & 6.10 & 7.71 & 5.15 \\
\hline Median Stone Diameter for riprap & : left & utment & & right & abutment, & ft \\
\hline Fr< $=0.8$ (vertical abut.) & ERR & ERR & ERR & $\mathrm{ERR}$ & ERR & ERR \\
\hline Fr>0.8 (vertical abut.) & 2.50 & 3.14 & 2.15 & 2.50 & 3.14 & 2.15 \\
\hline
\end{tabular}

